\title{
THE HABITS AND DEVELOPMENT OF THE NEWT (Diemyctylus viridescens).
}

\author{
EDWIN O. JORDAN.
}

\section{TABLE OF CONTENTS.}

Introduction

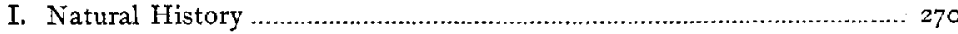

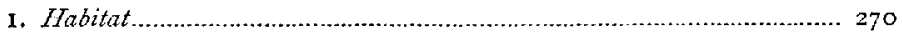

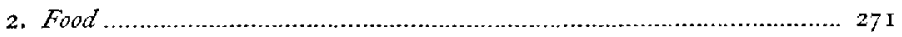

3. Spermatophores ................................................................. 273

4. Receptaculum seminis............................................................. 274

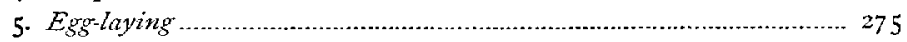

6. Transformations ................................................................. 279

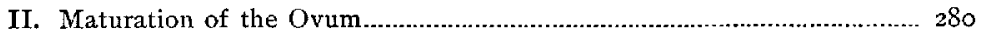

I. Technique ...................................................................................... 280

2. Origin and development of the ovum as a whole.............................. 282

3. Yolk-nucleus ............................................................................... 284

4. Yolk formation ....................................................................... $29 \mathrm{I}$

5. Germinal vesicle as a zehole ..................................................... 294

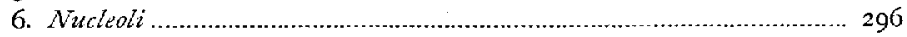

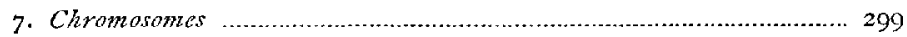

8. General considerations ................................................................. 300

9. Atrophy of the germinal vesicle and formation of the polar bodies... $30 \mathrm{r}$

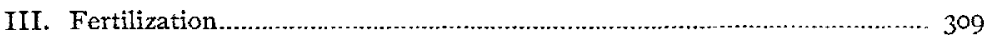

1. General phenomena .................................................................... 309

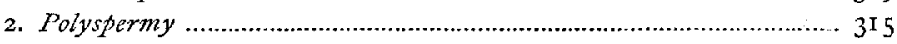

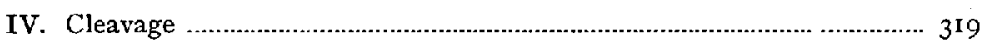

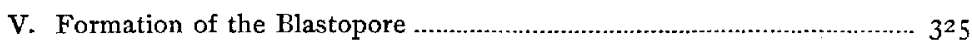

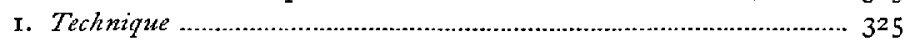

2. Segmentation cavity .................................................................. 327

3. External appeanances ............................................................... 328

4. Invagination ............................................................................ 328

VI. Fate of the Blastopore ..................................................................... 334

I. Method of closure of the blastopore .................................................. 336

2. Neuropore and anus....................................................................... 340

3. Primitive streak .......................................................................... 34I

VII. Germ-layers and Notochord ............................................................... 347

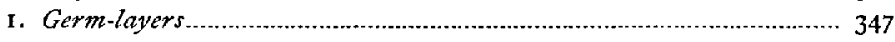

2. Notochard …........................................................................... $35 \mathbf{I}$ 
THE work embodied in this paper was carried on at Clark University during the winters of $\mathrm{I} 890-9 \mathrm{I}$ and $189 \mathrm{I}-92$, and during the summers of the same years at the Marine Biological Laboratory at Wood's Holl.

I gladly avail myself of this opportunity to acknowledge my great indebtedness to the University authorities for the privileges accorded me, and for the readiness with which every facility for work has been freely granted. I am under particularly deep obligations to Professor Whitman, in whose laboratories my studies have been pursued, and who has constantly furthered my work with inspiring suggestion and advice.

Through the kindness of Mr. A. C. Eycleshymer I have enjoyed the valuable privilege of comparison of certain stages of my work with his unpublished results upon Amblystoma. Such comparison has been of great service to me and I gladly acknowledge my indebtedness to him. To my friends Drs. Wheeler and Watasé I am likewise deeply indebted for many friendly courtesies.

\section{Natural History.}

The smaller North American newt or "water-lizard" (Diemyctylus viridescens, Raf.) is widely distribute throughout the northern and eastern part of the United States, and may be obtained easily and in great abundance.

My investigations have been made chiefly upon newts collected in the neighborhood of Worcester, Massachusetts. The animals in that locality can be readily captured with blind sweeps of a net in small shallow pools of a few feet in diameter, and also in ponds and lakes of considerable size. They frequent, for the most part, places with a soft, muddy bottom and an abundance of water plants such as Anacharis, Fontinalis and Ceratophyllum; in such spots they usually conceal themselves under fallen leaves and among the tangle of water weeds. On warm, sunny days in early spring, however, they bask openly in the sunshine in the shallow water close along shore. They are not as a rule found in swiftly running water; and in the large ponds they appear to prefer small bays and coves sheltered from the wind. 
The males considerably outnumber the females; of 426 individuals taken from many different localities at different times 280 were males. ${ }^{1}$ The females are slightly larger and in the breeding season considerably heavier than the males. The five largest individuals measured were three females, respectively $I I .3 \mathrm{~cm}$., $I I \mathrm{~cm}$., $10.6 \mathrm{~cm}$., in length, and two males $10.5 \mathrm{~cm}$. and $10.2 \mathrm{~cm}$. The newts obtained from ponds of some size are as a rule larger than those from smaller bodies of water.

Food, etc. - The newts in their natural habitat are carnivorous. They are exceedingly voracious, and when freshly captured almost invariably have their stomachs distended with partly digested prey. They feed chiefly upon insect larvae and small mollusks which they swallow bodily. Among the most common objects in the stomachs of the newts are the mollusks, Bythinella, Valvata, Planorbis and Cyclas; orthopteran and dipteran larvae; small water-spiders ; encased Phryganid larvae ; small crustacea and the like.

The females will take food eagerly all through the time of egg-laying. In this respect they differ from Necturnts and from Amblystoma, since in the breeding season these larger urodeles refuse to take food. The longer duration of the period of oviposition in the newt as compared with many other amphibia may perhaps be correlated with this absence of the fasting habit.

In captivity, newts may thrive for several weeks without being fed, although they are kept in best condition by feeding about three times a week with earth-worms or with finely chopped beef. They become very tame in confinement, and exhibit a lively interest in the preparations for feeding them, even jumping an inch or two out of water to catch a piece of meat held over them by the forceps. They do not, however, discriminate between the meat and the point of one's finger, and will often leap into the air after the bare forceps. They

1 In the breeding season both sexes, particularly the males, lose some of their shyness and may be observed in their natural habitat without difficulty. Each female is usually surrounded by several - sometimes as many as ten or twelve suitors. 
appear generally to recognize the presence of food by smell or taste rather than by sight. If a few bits of chopped meat are put quietly into an aquarium the newts at first take no apparent notice of its presence, but after a few seconds they begin to stir around uneasily and are soon moving slowly over the floor of the aquarium with noses close to the bottom like hounds on the scent. As soon as a morsel of meat comes in contact with the snout it is snapped up with a quickness that is in marked contrast to the newt's previous ignorance of its precise whereabouts. When roused or very hungry, however, the newts will catch bits of sinking meat, rapidly swimming insect larvae, water beetles, and other moving objects. It seems reasonable to suppose that there are tactile corpuscles on the end of the snout which impart this ability to detect objects in motion. It often happens that when several newts are being fed together in the same aquarium, the legs and tails of some of them are snapped at by their indiscriminating fellows with quite as much avidity as are pieces of meat. The individuals thus attacked frequently emit a faint cry or squeak resembling the sound made by drawing a wet finger rapidly over a plate of glass.

In such cases, where the stimulus of the neighborhood of food causes the newt to snap at any moving object without regard to the object's connections, it certainly seems as if tactile and not visual sensations must be predominant. Bateson ('89) has shown that many fishes, such as the skate, dogfish, sole and sterlet, habitually rely upon scent (taste?) and to some extent upon touch in seeking their food, while sight plays little or no part. The newts appear in this respect to resemble closely these fishes. In the newt, as in other aquatic animals, there is probably little distinction to be drawn between taste and smell. The stimulus must necessarily be a special molecular vibration that informs the animal of the presence of a distant object. The sense is like that of "smell" in obtaining cognizance of bodies at a distance, and like that of "taste" in obtaining it through the medium of a solution.

With proper food and care newts are easily kept for a long time in captivity. I have kept 250 of them in aquaria from 
October to May with only ordinary care and attention, not one of them dying during this time. I have also been able to obtain them directly from the ponds as late in the season as the I6th December and as early as the $22 \mathrm{~d}$ February.

Spermatophores, etc. - I have described in an earlier paper (91) the chief phenomena attending the deposition of spermatophores, and need here add little to that description. Gage ('91) has recently observed the deposition of spermatophores in the autumn, which occurs "exactly as described for the spring," and the same interesting occurrence is also noticed by Zeller ('91). This curious anticipation of the normal breeding season I had previously observed, and at first regarded as due simply to the forced association of the two sexes in captivity at a somewhat higher temperature than that to which they are accustomed in their natural habitat, but I have since seen reason to think that production of spermatophores may take place sporadically in the autumn under natural conditions. I have on several occasions in the autumn months seen pairs in the ponds engaged in the preliminary "Liebesspiel," but have at no time observed any approach to such an outbreak of sexual susceptibility as occurs in early spring. The observations of both Zeller and Gage were made solely upon specimens in confinement where the influences I have indicated above must be potent. There is no doubt, however, about the fact that spermatophores are sometimes discharged in the fall, whereas, in the midsummer months, so far as my observations go, this discharge does not occur, even in individuals in captivity.

The seminal receptacles of females captured in the autumn usually contain spermatozoa, although not in the same abundance as in spring. One may account for the presence of the spermatozoa by supposing either that they are the acquisition of a recent mating, or that they have been kept over from the preceding spring. It is possible that both explanations are valid in individual cases.

It is not very uncommon to see two males in the aquaria pass through all the stages of the Liebesspiel, even to the discharge of spermatophores, exactly as if they were of 
opposite sexes, but I was somewhat surprised to witness the same singular occurrence in the ponds and to repeat this observation on several occasions. The males in the aquaria are frequently attracted (by the odor?) toward a male that has just left a female and often succeed in frightening the female away; they then temporarily usurp her function, and by vigorous pushing against the cloacal region of the unsuspecting male in front cause him to discharge fruitlessly several spermatophores. ${ }^{1}$

Receptaculum seminis, etc.-At about the same time that my paper upon the spermatophores appeared, Alfred Stieda ('9I) published a description of the receptaculum seminis of the female European triton which renders superfluous any detailed description of this structure in Diemyctylus. Stieda's description appears to me fairly adequate, and agrees in all essential particulars with my own observations upon our North American genus. Stieda charges Heidenhain ('90) with having overlooked the function of the receptaculum in calling it a "rudimentary gland," but in making this charge lays himself open to the suspicion of having made an oversight of his own. The "rudimentary gland" referred to by Heidenhain (p. 201, et. seq.) as the homologue of the "Bauchdriise" of the male exists, as Heidenhain states, in addition to the receptaculum. It seems probable that Stieda completely missed this structure. It is hardly likely that any one could mistake the female receptaculum for a "rudimentary gland."

Stieda apparently does not believe that the cells lining the receptaculum seminis have any secretory function whatever, although his figures assuredly do not forbid the assumption that such is the case. I have not found in Diemyctylus any convincing evidence that these cells are truly secretory, but if we regard them as mere passive linings to the walls of the tubules, it is difficult to account for the entrance of the

1 Fig 2, Plate XV. represents a spermatophore just after deposition. It was stated in my earlier paper, through an oversight, that the gelatinous base of the spermatophore measured about six millimeters in diameter; the correct statement should read "about nine millimeters," though the size of the spermatophore is quite variable and depends on the size of the male discharging it. 
spermatozoa. If I understand Stieda correctly he does not regard the receptaculum of the female as corresponding to any of the glandular structures so strongly developed in the male. A direct homology of the receptaculum with the pelvic gland of the male has, however, been affirmed without hesitation by Blanchard whose opinion I have quoted elsewhere ('91), and of whose work Stieda seems to have been ignorant. As regards Diemyctylus, the male pelvic gland certainly seems to occupy a position precisely equivalent to that of the receptaculum, but it is clearly futile to pronounce upon the absolute homology of the two structures without some study of their development, and this I have not made. The question is probably a barren one.

Fischer ('91) has recently discovered the receptaculum in Geotriton, and, like Blanchard, homologizes it with the pelvic gland of the male, "da es nämlich die entsprechende Lage einnimmt." The receptaculum in Geotriton, according to Fischer, is unpaired. The tubules of the individuals that he examined contained no spermatozoa. ${ }^{1}$

Egg-laying, etc. - Females that have been kept in confinement all winter are not so apt to lay eggs in the spring as are individuals freshly captured. In some few cases I have obtained eggs from females kept in my aquaria during the winter, but, as a rule, only females taken during the spring months can be relied upon to furnish eggs in any number. Egg-laying begins about the Ioth April and is brisk until the first of June, then slowly falls off, and practically ceases by the first of July. It is probable that for a single individual the egg-laying season lasts for at least seven or eight weeks. The longest time over which I have actually observed the laying of a single

\footnotetext{
1 Fischer has drawn a curious conclusion from the presence of the receptaculum: "Wenn man sich noch einen Augenblick die Lage des receptaculums vor Auge hält, wie es gegenüber den Oviducten liegt, wie hier der Samen jeden Augenblick bereit steht, um zur richtigen Zeit in den Uterus zu gelangen, so ist wohl richtig, was oben schon als wahrscheinlich bezeichnet wurde, dass der Geotriton fuscus zu lebendig gebärenden Amphibien gerechnet werden muss." (Fischer ('91), p. 24.) It is not at first glance apparent how the presence of a receptaculum renders any greater the probability that Geotriton produces living young! A receptaculum exists in many egg-laying amphibia - to say nothing of other animals - and its presence or absence is not correlated in any way with viviparity.
} 
individual to extend is four weeks, but in this case the ovaries still retained large pigmented eggs, and under perfectly normal conditions egg-laying would undoubtedly have continued for some time longer. The appearance of the ovaries of freshly captured females which I examincd at frequent intervals throughout the laying season fully justifies this view.

The largest number of eggs that I have observed a single female to lay in captivity is shown in the following table :-

\section{Eggs laid by one female.}

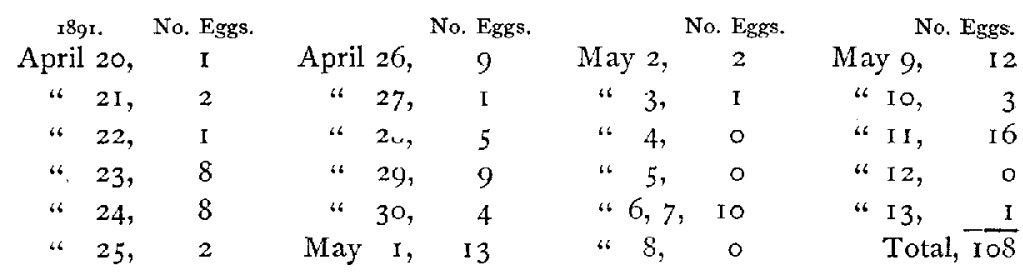

In this particular instance the female was not in company with a male after the $24^{\text {th }} \Lambda$ pril, yet she continued, for nineteen days after her separation, to lay eggs that developed normally. If she had been under perfectly natural conditions it is probable that she would have still continued to lay, since her ovaries were tolerably well filled with large pigmented eggs. It will be noticed that the number of eggs - ninety-six - laid after separation from the male is considerably larger than that observed by Gage who found indications "that for a single mating about six eggs may be internally fertilized, about the number found in the oviducts at one time." ('91, p. I091). Numerous other observations corroborate my figures above. Furthermore, I have reason to think, as I shall state in the sequel (p. 309), that fertilization of the eggs does not take place in the oviducts. When egg-laying ceases prematurely it seems. to me that it must be for other reasons than lack of male elements, since the supply of spermatozoa in the receptaculum is practically inexhaustible. It does not seem to me necessary that more than one mating should occur in a single season, but I agree with Gage that in a state of nature several matings of the same female may and frequently do take place. 
The eggs are laid singly as a rule, but occasionally two, and rarely three, may be deposited successively in the same nest. The eggs are laid between folds of a leaf of Anacharis or some similar water plant, or in a bunch of Fontinalis leaflets. (Fig. I, Plate XV). I have found eggs in the ponds wrapped in the same elaborate fashion as those laid in my aquaria. The eggs in the ponds are laid upon water plants in the localities usually frequented by the newts, and may sometimes be obtained in considerable abundance. The selection of a suitable spot for the laying of an egg often gives the female some little concern, since she is rather fastidious in this particular, and will wander from plant to plant until a thoroughly satisfactory place is. found. She then bestrides the chosen spray of water plant, and gathers in with her hind legs the surrounding shoots, pressing them close around her cloaca. She next turns on her side or occasionally on her back, and, with forelimbs outstretched and rigid, with hind-limbs and twigs completely hiding her cloaca, usually remains perfectly motionless for about six to eight minutes. At the end of this time she slowly leaves the "nest," which now holds an egg well protected by a tangle of shoots glued together by the gelatinous secretion poured out of the cloaca.

I have observed a female begin to lay an egg five minutes after laying the preceding one, but this is the shortest interval that has come under my notice; usually the time elapsing between the deposition of two eggs is considerably longer than this. The largest number of eggs that I have secn laid by one individual in the course of twenty-four hours was seventeen.

The ripe ovaries of adult females consist of two paired sacs applied more or less closely to the dorsal wall and extending nearly the whole length of the body cavity. In an individual measuring about 9. I centimeters from tip to tip, the ovaries, when in position, are about I.7 centimeters long, but they are flexed considerably upon themselves so that, when straightened, they are fully twice that length. These sacs are composed of two folds of epithelium, between which lie the eggs ; Schultze ('87) has appropriately called the outer of these layers the "Peritonealepithel," and the inner the "Innenepithel." 
The number of eggs in each ovary and the weight of the ovaries, are indicated in the following table :

\begin{tabular}{clllll} 
& & \multicolumn{3}{c}{ No. Eggs } & No. Eggs \\
Length of Animal. & Weight. & Wt. Rt. Ovary. Rt. Ovary. Wt. Lft. Ovary. & Lft. Ovary. \\
$9.1 \mathrm{~cm}$. & 3.20 grm. & .17 grm. & 216 & .20 grm. & 236 \\
9.0 & 2.54 & .13 & 248 & .12 & 193 \\
9.2 & 3.24 & .21 & 254 & .17 & 174 \\
9.6 & 4.32 & .33 & 326 & .15 & 162
\end{tabular}

The relative weight of the mature ovaries to the weight of the whole body is about one to nine. The " number of eggs " given in the table is the number plainly visible to the naked eye; the number visible with even a low power of the microscope is of course far greater than this. The number of large pigmented eggs measuring approximately one millimeter in diameter is about forty per cent, of the number given in the table. All of these pigmented eggs are in ordinary circumstances deposited in a single season; the number of eggs laid by a good-sized female every year is consequently about I 80-250.

The ovaries of females captured at the close of the breeding season contain no large pigmented eggs, and are stringy, lightcolored and greatly shrunken. The weight of the ovaries has greatly decreased as shown in the following table :

$\begin{array}{clcc}\text { Length of Animal. } & \text { Weight. } & \text { Weight of Right Ovary. } & \text { Weight of Left Ovary. } \\ 8.2 \mathrm{~cm} . & 1.86 \mathrm{grm} . & .03 \mathrm{grm} . & .03 \mathrm{grm} . \\ 9.1 & 2.03 & .02 & .02 \\ 8.9 & 2.01 & .01 & .01 \\ 10.0 & 2.3 \mathrm{I} & .01 & .01\end{array}$

That is to say, about one-tenth of the body weight is discharged in the form of eggs every year. It may be noticed also that the weight of females captured at the close of the laying season is distinctly lower than that of females taken in early spring. The average weight of the former is $2.05 \mathrm{grm}$. ; that of the latter, less the average shrinkage of the ovaries, 2.74 grm., while the average length of the individuals composing the two groups is about the same. This result is substantiated by other weighings and measurements which it is not necessary to give in detail. There is hence a loss of bodyweight, in addition to the direct loss of egg-substance, during 
the laying season, amounting possibly to one-fourth of the total weight. This may be partly due to the not inconsiderable amount of substance that goes to form the protective membrane of the egg, and partly to the conversion of body-substance into yolk during the laying season. One might be tempted to explain this loss of body-weight by increased katabolism of the tissues, due to higher temperature, were it not for the fact that the males, although strikingly thin and exhausted at the end of the period of "Liebesspiel," gain rapidly in plumpness and weight as the summer advances. The true explanation seems to lie rather in the directions first indicated.

Transformations, ctc.-Gage ('91) in his recent interesting paper, describes and figures the external developmental stages that the newt passes through, and arrives at the important conclusion that the well-known red, terrestrial form - the so-called variety miniatus - is merely a stage in the life-history of the species, and is not to be regarded as a distinct variety. Although I have not had these animals under observation longenough to warrant me in expressing a very decided opinion on this point, I feel fairly confident, from what I have seen, that Gage's main contention is correct. One of the first things that strikes the collector of the aquatic form is the comparative absence of all newts below a certain general grade of development. These young and immature individuals are not to be found in water, by using a net with finer meshes, but may be discovered on land by turning up the stones and logs on the shores of the pond, and one is hence tempted to infer what Gage has concluded, viz. that the red, terrestrial form is merely an immature condition of the common aquatic newt. Gage has given us an interesting discussion of the causes that may have led to this curious change of color and habitat.

I do not yet feel prepared to say that I regard the assumption of the terrestrial habit as a necessary stage in the development of every individual. It is quite possible that certain individuals attain maturity without ever leaving the water, although perhaps the great majority of newts pass their Wanderjahre on land. 
I may add that Gage has appended to his paper an annotated bibliography that must win the gratitude of future students of the natural history of the newt.

\section{Maturation of the Ovum.}

The phenomena of maturation may be taken in their broadest sense to include all the progressive changes in the ovum from its youth up, and cannot strictly be limited to the nuclear changes immediately preceding fertilization. Indeed one may hold with some reason that the early stages of oögenesis are no less significant than the later.

In amphibian ova two general stages of development may conveniently be distinguished : the early, constructive, or as it may be called, anabolic period, during which the yolk is elaborated and the full size of the ovum reached; and a second period, beginning with the remarkable regressive metamorphosis of the germinal vesicle, and culminating in the expulsion of the polar bodies. The accumulation of yolk may be considered quite as essential to "ripeness" as the extrusion of nuclear substance, since, so far as we know, both are invariable preliminaries to the normal union of male and female pronuclei. It is a fact especially worthy of notice that the germinal vesicle undergoes a progressive development up to the time when yolkformation is practically completed, and only then begins to show signs of degenerative change; this significant fact must be taken into account in all conjectures as to the functional rôle of the amphibian egg-nucleus.

The maturation phenomena in amphibian ova have been so often and so thoroughly studied, that, where my observations are in full harmony with those of my predecessors, I shall either refrain from all reference to the fact, or shall content myself with bare mention of it without entering into superfluous details.

Technique. - I have found the two most satisfactory killing agents for the ovarian eggs to be hot water $\left(80^{\circ} \mathrm{C}\right.$.), and Flemming's chrom-aceto-osmic mixtures. In my experience I have found no advantage in leaving the eggs longer than two hours in Flemming's mixture, and though I have used a solu- 
tion of the strength recommended by O. Schultze (87) I have not reached his successful result with so long an immersion as twenty-four hours. This may perhaps be due to the comparatively small size of Diemyctylus eggs and their consequent speedier penetration by the fluid.

After an immersion of two hours in Flemming's mixture the eggs are washed repeatedly with distilled water and 35 per cent. alcohol, and then transferred to 50 per cent. alcohol, where they remain for an hour, after which they are hardened in 70 per cent. alcohol for from twelve to eighteen hours. They are finally passed successively through 95 per cent. alcohol, absolute alcohol and xylol (or turpentine), not remaining above an hour in each, and are imbedded in paraffine. After repeated trials of Schultze's method of leaving the exgrs for twenty-four hours in each of the different grades of alcohol, I was obliged to abandon it as eminently unsatisfactory for Diemyctylus eggs. A short stay in the alcohols afforded me much better results.

I have stained in toto by putting the eggs, after their stay in 70 per cent. alcohol, into borax carmine or alum cochineal for twenty-lour hours, and have in this way obtained excellent preparations, particularly with the cochineal. For staining on the slide I have used Mayer's method of fastening the sections to the slide with albumen fixative.

If the eggs are killed with hot water and then passed slowly through rising grades of alcohol the results are quite as satisfactory as those reached with Flemming's mixture. In some respects, even, they surpass the latter, since shrinkage of the germinal vesicle is less frequent with hot water than with any other method. The eggs are dropped into water of about $80^{\circ} \mathrm{C}$. for a few seconds, and then passed at once into weak alcohol and slowly up to the higher grades.

Perenyi's fluid and Kleinenberg's picro-sulphuric mixture do not seem well adapted for use on the ovarian egg. The latter, in particular, badly distorts nuclear appearances.

For study of the young living egg I have relied chiefly upon examination of perfectly fresh specimens in physiological salt solution, though I have found both silver nitrate and methyl green very helpful in determining certain points. 
Origin and Developmeni of the Owum as a Whole. - I have not yet completed my study of the differentiation of the germcells in the larva, and shall confine myself here to a brief description of the formation of the ova in the mature female. In the adult, as has been stated, the ova arise between two folds of epithelium and originate directly from the epithelial cells of the outer or so-called germinal epithelium (Fig. 4, Pl. XV). My observations on this point agree substantially with those of Iwakawa ('82), and I have frequently found in silver nitrate preparations appearances like those figured by him in Figs. 3, 5, and 6, P1. XXII. The epithelial cells that give rise to ova are to all outward seeming exactly like the other peritoneal cells. As soon as the germ-cell becomes recognizable as such, other epithelial cells are seen crowded around it, and eventually some of these form the follicle cells of the young ovum.

I have not been able to determine to my own satisfaction whether follicle cells and ovum originate immediately from a single germinal epithelium cell, or whether the young ovum is a lineal descendant from a primordial ovum and the follicle cells from primordial follicle cells. Considered cytogenetically, however, both follicle and ovum, if the line of cell descent only be pushed back far enough, must have had a common origin from a single cell somewhere in the developmental history of the larva. There is no valid morphological support for a belief in an early analysis into definite ova on the one hand and into definite follicle cells on the other, and I can see no inherent improbability in the view that the analysis into ovum and follicle occurs at a comparatively late stage in the development of the germinal epithelium.

At the same time, however, I incline to the view taken by Iwakawa ('82) and Hoffmann (86) that the follicle takes its rise from the germinal epithelium contemporaneously with the ovum, and that follicle and ovum do not have immediate origin from the same cell. Fig. 4 shows a well developed ovum, with the follicle cells just beginning to grow over it from the superjacent epithelium, and indicates a condition similar to that described by the observers just cited. The cells of the 
germinal epithelium abutting on the germ-cell appear to accompany the latter in its passage below the surface, and to become its enveloping sheath. But I cannot regard these appearances as conclusive and must still leave open the possibility of a late "analysis" of one of the "primordial ova" into true follicle and ovum. It is an hypothesis not altogether without warrant that all the germinal epithelium cells may at the start be very similar, or even identical, and that local conditions may bring it about that some shall develop into ova and others into follicle cells.

Starting with the young ovum just sinking beneath the surface of the other germinal epithelium cells we may conveniently separate its history into the two periods already mentioned, the period of the accumulation of food-stuff, and the period of the changes that qualify the female nucleus for union with the sperm nucleus. The first period is marked by the advent of new elements in the cytoplasm, and by rapid increase in size of the ovum; the second by the comparative cessation of cytoplasmic phenomena, and by striking internal changes in the germinal vesicle.

The germinal vesicle in a young egg, before any yolk spherules are apparent, is about half the diameter of the egg itself, measuring .07 mm. in an egg. $13 \mathrm{~mm}$. in diameter. Fig. 4 shows that in an even younger stage the germinal vesicle occupies a slightly larger proportional share of the egg space. The egg as a whole increases in size though not in complexity up to a diameter of about .3 to $.4 \mathrm{~mm}$. when the first traces of yolk begin to darken the field. (Fig. 7, Plate XV.) The germinal vesicle up to this time has increased pari passu with the whole egg, and in an egg of $.4 \mathrm{~mm}$. in diameter measures $.2 \mathrm{~mm}$. From now on, however, while the yolk is gradually forming, the growth of the whole egg far outstrips that of the nucleus. In an egg of $1.3 \mathrm{~mm}$., which is very nearly the average size of mature eggs, the germinal vesicle is only about .3 to $.4 \mathrm{~mm}$. and rarely exceeds that proportion. In other words the volume of the germinal vesicle compared with the volume of the whole egg before yolk formation is about $\mathrm{r}: 8$; in the mature egg it does not exceed $\mathrm{I}: 35$. 
The stage of pre-eminently cytoplasmic phenomena to which we first turn is distinguished in amphibian ova by the appearance and elaboration of the yolk, and by the advent of certain enigmatical structures, the so-called yolk-nuclei.

Yolk-nucleus. - The so-called yolk-nucleus (Dotterkern) of the amphibian egg appears to have been first observed by Cramer (48) who discovered it in the ovarian eggs of Ranc temporaria in $\mathrm{I} 846$. He describes it as a "little ball of granules," which, as the egg becomes larger, spreads out into "an elegant half-moon" around the germinal vesicle, and, finally degenerating, mixes completely with the substance of the egg. In the previous year a similar body had been seen by v. Wittich ('45) in the ovarian eggs of spiders, but whether this concentrically ringed structure is in any way comparable with the body found in the amphibian egg was then and is still to this day an open question. Further studies by v. Wittich, v. Siebold and Carus failed to shed much light on the significance of this concentric body in spiders' eggs. v. Wittich ('49) found it upon the surface of the yolk in freshly laid spider eggs, and speaks of it as "a hollow, thick-walled capsule filled with liquid." Carus ('50) was the first to apply the name Dotterkern to this element of the egg. He refers to Cramer's observations upon the similar body in the egg of the frog, and is inclined to homologize the two structures.

Practically nothing was added to these early and fragmentary observations upon the yolk-nucleus until the investigations of Lubbock and of Gegenbaur in I861. Gegenbaur (61) discovered in the avian egg " einen fast scharf umschriebenen runden Fleck . . . mit dem Keimbläschen hat er keine Beziehung, denn dieses liegt immer entfernt von ihm." Gegenbaur does not commit himself to any definite view on the significance of this "constant element" of the egg, but is evidently inclined to regard it as in some way connected with the origin of the yolk granules.

Lubbock ('61) described and figured a body which he observed in young Myriopod eggs of several genera, but was doubtful as to its homology with the concentric structure observed in Arachnid eggs, and prudently refrained from at- 
tributing any special importance to it. "I have," he writes, "several times been inclined to look upon it as a mere accidental agglomeration of yelk; but it is, I think, too regular and too constantly present."

Since I $86 \mathrm{r}$ the yolk nucleus has been described and figured by nearly every worker upon Arachnid, Myriopod or Amphibian ova. An analogous body has also been observed in Crustacea (Reichenbach, '77), in Mollusca (v. Ihering, '77), and many other groups, but it is doubtful if there is any community of relation whatever between these structurally different bodies. With few exceptions these numerous observations have done little towards explaining the significance of the "yolk nucleus" in any one of the groups of animals in which it appears.

Balbiani $\left({ }^{\prime} 4^{a},{ }^{a} 4^{b}\right)$ was the first to observe the yolk-nucleus in the egg of Myriopods (Geophilus), where it appeared to him as "une petite vésicule," much smaller than the germinal vesicle, and lying close to the periphery of the egr. $\mathrm{He}$ describes circumstantially the formation of a layer of granules around the vésicule and the subsequent migration of these granules to distant parts of the egg. It was chiefly this phenomenon that led him to believe that the small vesicle was the formative center for the nutritive elements of the egg. He also advanced the view that the substance of these eggs consists of a "partie germinative fondamentale et d'une partie nutritive, chacune de ces partics se constitue isolément et pour son propre compte." This separation between the germinative and nutritive elements is, according to Balbiani, primordial, and dates from the first stages of the egg.

In a paper published some time afterwards, Balbiani (73) modifies his views regarding the "cellule embryogène" as he now prefers to call it. From his observations upon the Teleostean egg he concluded that the cellule has its birth in the epithelium of the follicle - in some such way as van Beneden and Julin ('87), and Morgan ('90) claim is followed in the formation of those strangely similar bodies, the Ascidian test-cells. In some Teleosts Balbiani finds a straight canal or pathway leading from the follicle into the 
egg substance, and his embryogenic cell lying at the bottom of this canal. He regards the external origin of this body as strengthening his view of a fundamental difference between it and the germinal vesicle and as an additional reason for insisting on the separation of the nutritive and germinative elements of the ovum. Balbiani does not agree with v. Bambeke that the embryogenic cell disappears before the egg reaches maturity, but holds that it persists even after fertilization.

In a later paper Balbiani ('83) brings forward some new observations, which, if confirmed, are certainly important. He finds that the eggs of Geophilus, when treated with dilute acetic acid show a process of the germinal vesicle which projects into the body of the egg. There are sometimes several of these processes, each process consisting of a double tube, the outer tube communicating with the nucleus, the inner with the nucleolus. The "vitellin protoplasm" at the outer extremity of these tubes becomes denser, and presumably receives substances through the tubes from the nucleus and nucleolus, and this vitelline protoplasm so comes to contain "tous les éléments d'une cellule"! These "corps intravitellins" then break away - though this part of the process was not directly observed - and can thereafter be recognized as true "noyaux vitellins." These "noyaux vitellins," according to Balbiani, now become follicle cells! Whether Balbiani's views have undergone any further modification since the appearance of this last paper I have no means of knowing, but must confess to some bewilderment at the kaleidoscopic comprehensiveness of the views just stated.

Schütz ('82) at about this time published a brief account of his work upon the Dotterkern - principally in Arachnids and after summing up the work of previous investigators concludes that the Dotterkern has a nutritive significance. Schütz, however, appears to have overlooked what was in many respects the soundest utterance on the amphibian Dotterkern. O. Hertwig ('77) observed the Dotterkern in the eggs of Rana, and concluded that very great morphological significance could not be attributed to it since it was not found in all amphibian ova. 
"Mir scheint er cinzig und allein mit der Bildung der Dottersubstanz in Beziehung und eine eigenthümliche locale Ansammlung von Nährstoffen darzustellen." Hertwig suggests the name "Dotterconcrement" as preferable to that of Dotterkern, and justly criticises the term Dotterkern as applicd to the body observed in the amphibian egg. I have, however, retained the name yolk-nucleus because of the wide currency that this name has already obtained, and because the designation "yolk-concrement" is open to the construction that this body is a mere concretion of yolk.

Sabatier ('83) describes the origin and fate of the yolk-nucleus as he observed it in the Arachnids: "né dans le voisinage immédiat de la vésicule germinative, il s'en éloigne progressivement. . . Il devient plus granuleux et se désagrège progressivement. Ses éléments divisés en petits globules indépendante sont en partic résorbés par le vitellus, ou s'introduisent en partie entre les grosses sphères vitellines et viennent sourdre à la surface de l'œuf pour se mêler au protoplasme granuleux superficiel." From these observations he draws the remarkable conclusion that the "noyau vitellin" is to be regarded "comme un élément de polarité mâle, qui se détruit comme tel pour accentuer et compléter la sexualité de la cellule femelle."

Will (84) advances a rather improbable view of the origin of these bodies in the amphibian and insect ova and appcars to regard the phenomena in these two groups as practically identical. According to his observations some of the nucleoli in the germinal vesicle of the amphibian egg reach a comparatively large size, but do not differ from the others in their behavior to staining fluids or other reagents. One or more of these enlarged nucleoli pass out into the body of the egg and there as "yolk-nuclei" take part in the formation of the yolk. Will finds some cases in which the nucleoli change into epithelial cells, but, since in the long run these share in the formation of the yolk the "Endproduct" is the same.

Stuhlmann ('86) describes the origin of the Dotterkern in the arthropod egg and seems to regard it as originating independently in the cytoplasm. "Niemals aber konnte ich eine 
Entstehung aus dem Keimbläschen constatiren, wie Balbiani dies für Geophilus und Will für den Frosch angiebt." Stuhlmann agrees with Hertwig and Schuitz as to the significance of the Dotterkern. "Der Dotterkern stellt eine Concretion von dem besonderem, von dem gewöhnlichem Dotter verschiedenem Nahrungsmaterial dar, das zu irgend einer Zeit vom Ei resorbirt wird."

The more recent observers of the Dotterkern have for the most part contented themselves with passing notices of its presence and general characteristics, and have not added materially to our knowledge of its relations and significance.

I have given this brief historical sketch of the observations on the "Dotterkern" as well for the purpose of calling attention to the interesting problems connected with this body, particularly in its occurrence in the Myriopod and Arachnid ova, as for emphasizing the entire absence of homology between the structures usually classed as yolk-nuclei.

In the newt the yolk-nuclei first become distinctly visible about the time of beginning yolk-formation, at which time several of these bodies appear nearly simultaneously in different parts of the egg. I have always found at least two and sometimes as many as nine in eggs of about the stage shown in Fig. 7. The number of yolk-nuclei in eggs of a more advanced development is no greater, and on the whole averages somewhat less than the number in eggs of this particular stage. I have no conclusive evidence of coalescence of these bodies, but am confident that some of them disintegrate. They all disappear completely some time before fertilization of the egg, and I have never been able to detect any trace of them in eggs that contained a maturation spindle.

In eggs of the stage shown in Fig. 7 the yolk-nuclei appear first as small, finely granular bodies, irregularly shaped and with their outlines poorly defined from the surrounding cellsubstance (Fig. II). They stain more deeply than the cytoplasm, but still very feebly as compared with the developing patches of yolk. At a still earlier stage I have observed an appearance which can be best interpreted as a localized condensation of cytoplasm and a consequent greater avidity for 
staining fluids (Fig. Io, Pl. XV). Whether or not these condensations are the immediate progenitors of such undoubted yolknuclei as that represented in Fig. I I, I am unable to decide, but it seems to me highly probable that such is the case. Between the latter and such complex bodies as that shown in Fig. I 3, Pl. XV. are found all gradations. I think it exceedingly probable that in the newt the yolk-nuclei always arise first as condensations of the cytoplasm and subsequently increase in size and complexity with the growth of the egg, ${ }^{1}$

At first they lie about half-way between the germinal vesicle and the periphery of the egg and often maintain this relative position for some time, but eventually they draw nearer to the germinal vesicle and in large eggs are usually found in close contact with it. It is not unlikely that they sometimes fuse with the substance of the vesicle, but from sections it is of course impossible to obtain absolute proof of complete fusion. Certainly a more common fate would seem to be the gradual disintegration of these bodies and the dispersion of the derived granules around the germinal vesicle in the manner described by Cramer ('48) and Schultze ('87). This breaking up of the yolk-nuclei appears to be their ordinary fate, and $I$ have often observed such a disintegration as is figured by Schultze (87) in Figs. $4 a, 4^{b}, 4 c, 4 d$. As the yolk-nuclei approach the stage at which this resolution into granules takes place, they generally assume a somewhat complex structure. They become more sharply marked off from the surrounding yolk (Figs. IO, I I, I 2 and $\mathbf{~} 3, \mathrm{Pl} . \mathrm{XV}$ ), and are usually differentiated into two elements, a coarsely granular portion staining feebly and resembling ordinary cell protoplasm, and a more compact portion of varying extent which stains deeply with carmine or alum cochineal. This highly stainable constituent often occurs irregularly disposed in two or more patches in a single yolk-nucleus as in Fig. 1 3, P1. XV, and Fig. I6, P1. XVI. This fact might perhaps be thought to countenance the view that these large yolk-nuclei arise from the union of several of the smaller bodies, but it is

\footnotetext{
II have never seen anything that would indicate that the yolk-nucleus arises from a large nucleolus which has migrated into the cytoplasm in the manner described by Will, and on this point am in full accord with Stublmann (86).
} 
the only observation I have made that would tend to such an inference, and cannot in itself be regarded as convincing.

The yolk-nucleus in the egg of the newt, then, arises from the cytoplasm, and usually disintegrates in the cytoplasm. It is likely, however, as I have already intimated, that yolk-nuclei are sometimes fused with the germinal vesicle. I am strongly inclined to believe that such fusion actually occurs, although I am unable to produce any very conclusive evidence in favor of such a belief. The fact that a considerable number of yolk-nuclei in late stages of the egg are sunk in a hollow of the vesicle, and in some cases almost surrounded by its substance, gives strong ground for such an opinion. In Fig. I6, P1. XVI, is shown a yolk-nucleus apparently coalescing with the germinal vesicle. The union in this instance is less pronounced than is sometimes the case, and I have frequently obtained preparations which show the yolk-nucleus engulfed to half its extent.

Not uncommonly the yolk-nucleus in these later stages appears to be split up into irregular polygonal fragments (Fig. I3), but as this does not appear to be invariable no great significance can be attached to it. It is very likely a mere sign of approaching dissolution.

It is evident, I think, if we compare the observations above recorded with those upon the structure and history of the "yolk-nuclei" in other groups of animals, that if all the observations of different authors are to be credited, any real homology between these bodies is out of the question. It is incredible that bodies so widely diverse in origin, structure and fate as the "yolk-nuclei" of Arachnids, Myriopods, and Amphibia should be homologous in any ordinary sense of the word. The only respect in which some of these bodies resemble one another is in appearing in the cytoplasm at some stage in the development of the ovarian ovum. It seems to be true, furthermore, that the yolk-nucleus is not of general occurrence in all species of the same group of animals. Although it is present in many amphibian eggs, according to Götte ('75) it is altogether absent in the ovarian eggs of Bufo and Bombinator. Indeed, it is said that yolk-nuclei are not always found in all the eggs of the 
same animal; this is stated by Iwakawa (82) to be the case with Triton pyrhogaster. These facts incline me strongly towards the view, also taken by Leydig, that the various structures usually grouped together under the name Dotterkern have nothing but the name in common.

I have here nothing to say upon the significance to be attributed to the curious bodies found in Myriopod and Arachnid eggs, and I cannot attempt to pass upon the peculiat views of Balbiani and Sabatier, but can only repeat that their explanations, however valid they may be for these particular groups of animals, are by no means satisfactory if applied to the amphibian Dotterkern.

We can from the nature of the case only surmise as to the physiological meaning of the bodies found in the amphibian egg. It is a seductive hypothesis that the amphibian yolknuclei are in some way concerned with the formation of yolk. The number, size, constancy, and complexity of structure of these bodies in the egg of the newt, their appearance about the time of beginning yolk-formation, and their disintegration or absorption after yolk-formation is complete, point to them as serving some physiological purpose during the building up of the cell. Whether they are, as Hertwig bclieves, "peculiar local gatherings of nutrient substances," or whether they are true formative centers, is a difficult question to determine. The fact that they have not been found in all amphibian ova is certainly against regarding them as of high importance, but it is premature to urge an objection based on negative observations. It is possible, and I think probable, that future investigation will show the yolk-nuclei to be of general distribution in all amphibian ova of certain stages of development. It appears to me certain that where the yolk-nuclei do occur they are not mere accidental agglomerations, but have a real physiological significance, probably related to the construction of yolk. I am strongly inclined to believe that the yolk-nucleus bears the same relation to the cytoplasm that the nucleoli do to the germinal vesicle.

Yolk-formation. - The yolk first appears when the ovum has reached a diameter of about .4 to .5 millimeters. A vacuolation 
of the cytoplasm, such as shown in Fig. 7, precedes the formation of the yolk itself. This is not a change due to reagents for it is shown in eggs killed with Flemming's chrom-osmoacetic mixture and other reliable reagents, and moreover appears only in eggs of a certain stage, younger eggs not displaying this vacuolated appearance. A similar arrangement of the protoplasm has been observed by Leydig ('88) in the young eggs of Triton taeniatus. The yolk is laid down upon these trabeculæ of the cytoplasm and in consequence of this arrangement often has in sections a distinctly reticulated appearance. Sometimes the yolk is formed first at one pole of the egg (Fig. 7) and then spreads to other parts, but I have not been able to discover any constancy in this polarity, or what relation such polarity bears to the pigmentation poles of the adult egg. More commonly the yolk appears nearly simultaneously in different parts of the cytoplasm and forms a more or less continuous ring. This ring of forming yolk is considerably nearer to the periphery than to the germinal vesicle, but never, at this earliest stage, lies in immediate contact with the follicle cells. The yolk patches are early distinguished by their great avidity for staining fluids, and by their high index of refraction and coarse granulation in unstained eggs. I have been able to discover nothing that would indicate that the yolk spherules increase by division; everything on the contrary indicates that they arise from points of independent origin. With a high magnification (I000 diameters) the beginning yolk patches show as in Fig. 5, Pl. XV.

I do not feel like speaking at all confidently as to the agencies concerned in the production of yolk. I have frequently observed appearances which may be interpreted as the stepping out of very minute granules from the germinal vesicle into the cell-body. These granules I have been unable to distinguish on the one hand from numerous small stainable granules (nucleoli?) inside the germinal vescicle or on the other from the granules of the forming yolk. Whether it is safe to regard this appearance as an actual migration of minute nucleoli which in persona propria become yolk spherules seems to me doubtful. There is, however, less objection to the view that certain 
deutogenic substances are formed in the vesicle, perhaps through the agency of the nucleoli, and are then sent forth to share in the building up of the cell. The peripheral position of the nucleoli in amphibian eggs, and their subsequent migration to the center after yolk construction has practically ceased may be best explained by supposing that in some way they take part in the management of deutoplasmic affairs. That either the germinal vesicle, as represented by the migrating granules, or the cytoplasm, as represented by the yolk-nuclei, is exclusively concerned in yolk-formation does not seem to me probable. If it be desired to formulate an hypothesis onc might suppose that granules from the germinal vesicles serve as starting points, centers of attraction or stimulation as it were, while the cytoplasm, perhaps through the mediation of the yolk-nuclei, elaborates and supplies the requisite deutoplasmic material out of nutritive elements furnished it by the follicle cells.

I may add that there is some support for such a view in the recent cytological work of Macallum (91). From studies upon the ovarian ova of Nectums and Rana, principally with the indigo-carmine stain, he draws the following conclusion: "The peripheral nucleoli generate a substance, therefore, which diffuses gradually through the nucleus, then into the cell protoplasm, the point of time of the latter occurrence corresponding with the formation of the yolk spherules. . . . I regard the yolk spherules as formed by the union of a derivative of the nuclear chromatin with a constituent of the cell protoplasm. . . The formation of yolk spherules in the cell protoplasm is analogous to the formation of zymogen granules in the pancreatic cells, and both are accompanied by changes in the nucleus and an increase in the cell protoplasm. It is most natural to conclude that the processes underlying the formation both of the yolk spherules and of the zymogen granules are in a general way alike." That there is some such sharing of nucleolar substance in cytoplasmic activities as Macallum here avers is a familiar and well-supported opinion.

Korschelt ('89) thus expresses a widespread conviction: "Ich muss es nach meinen Erfahrungen, die an Eiern und anderen 
Zellen gemacht wurden, als zweifellos hinstellen, dass eine Auflösung der Nucleolarsubstanz stattfindet. Die Erklärung dieser Erscheinung fand ich darin, dass die Nucleolarsubstanz in und vielleicht auch ausserhalb des Kerns zur Verwendung gebraucht werden sollte" (p. I 1 2). My own observations upon the position and behavior of the amphibian egg nucleoli lead me to endorse this view.

Germinal vesicle as a whole. - The germinal vesicle is derived from the nucleus of the germinal epithelium from which the egg first springs. I have never seen any appearances which would indicate that it arises from the union of several epithelial nuclei.

The germinal vesicle, while still very young, shows a differentiation of its substance into three elements - nuclear sap, nucleoli, and chromatin threads or, as I may call them at the outset, chromosomes (Fig. 4). The history of these two important chromatic elements will be dealt with in detail presently.

A nuclear membrane is visible in the young egg and comes out particularly well in fresh preparations treated with methyl green. This membrane cannot be detected in sections through late stages of the vesicle, but I have not been able to discover the precise period at which it disappears. Its disappearance seems, however, to be contemporaneous with the general vesicular atrophy.

The amphibian germinal vesicle sometimes presents, as observed by $O$. Schultze, Will, Götte and others, an irregular and often ragged contour. This has been considered to indicate amoeboid movements on the part of the vesicle similar to those witnessed in the nucleus of insect eggs. Schultze ('87) has given several figures illustrating this condition, - Figs. 5, I 8, 19, 20. In Diemyctylus I have observed this appearance only in rather young eggs, and in these the germinal vesicle has assumed the form shown in Schultze's Fig. 5, with sharp projections and jagged contour. Germinal vesicles in newts' egg of the same age as the ones shown in Schultze's Figs. I8 and 19, rarely, if ever, display these "amoeboid movements." The outer boundary, on the contrary, is smooth, even, and at 
most slightly crenated (Figs. I4, I5, I6). In eggs killed with hot water I have never found such an appearance as Schultze depicts in Fig. I8. With other methods of killing, however, I have sometimes seen a similar pseudopodia-like outline to the germinal vesicle. Since the penetration of any irritating fluid into an amphibian egg must necessarily be far from rapid, it seems possible that the germinal vesicle may be stimulated to slight amoeboid movements; so that while in one sense the "pseudopodia" may be an artificial product, in another sense they may be the expression of potcntial amoeboid capabilities. While I incline, therefore, to the belief that amoeboid movements in the older vesicles are not, in Diemyctylus at least, usual and normal occurrences, I am in full accord with Schultze as to the reality of these appearances in young eggs, and can confirm his statement as to the presence of both amoeboid and resting nuclei side by side in the same preparation. It is impossible to set a precise limit to the ceasing of these amoeboid phenomena, but in a general way I can say that it is extremely rare to find germinal vesicles with pseudopodia after migration of the nucleoli has begun.

I have never seen the pseudopodia of the vesicle stretch out into the ccll and engulf bits of nutrient substance as some observers (Brass) claim to have done, but I nevertheless agree with Korschelt (89) that the amoeboid movements of the young vesicle are of nutritive significance, and possibly aid in the diffusion of fluid from the nucleus into the cell. In the eggs of Rana palustris I have frequently observed the appearance depicted in Fig. I7. The peculiar amoeboid structure at the center of the vesicle with nucleoli clustered around it might almost suggest that the nucleoli had been drawn to the center rather than migrated there independently. I have, however, never observed such an amoeboid center in the germinal vesicle of the newt.

The curious recticular structure of the germinal vesicle which Iwakawa ('82) has figured in Figs. I9 and 27 is, I am inclined to believe, delusive. I have obtained a similar appearance with the use of picro-sulphuric mixture, but not with hot water, corrosive sublimate or Flemming's mixture. One would 
expect truer pictures of nuclear structure with the use of the latter reagents than with the former, but one cannot completely exclude the possibility that, as regards this particular character of the nucleus, the picro-sulphuric mixture preserves the natural aspects better than the other killing fluids named. I do not, however, believe that such is the case, and I consider the reticular appearance as probably due to the action of the reagent.

With regard to the accumulation of fluid around the germinal vesicle in advanced stages I agree fully with $v$. Bambeke, Hertwig and Schultze, that it is not a natural condition, but is caused by osmotic action during the processes of killing and hardening. When the egg is hardened slowly in rising grades of alcohol this escape of fluid does not occur, and the germinal vesicle impinges directly upon the yolk. (Figs. 1 5, I6, I7).

Nucleoli. - The nucleoli in the young egro appear arranged along the chromatin threads, and possibly originate from the thread substance. It is very difficult to determine just what relation the nucleoli bear to the threads in the earliest stages. The fact that the two structures are in the closest contact does not exclude the possibility of distinct and independent origin. The nucleoli are at first, to all appearances, integral parts of the threads, at least as much so as the highly refractive granules of the threads shown in Fig. I 4, Pl. XV. I must leave it an open question just how far it is safe to regard the early association of nucleoli and threads as indicating a common origin.

In eggs somewhat younger than Fig. 4 the nucleoli exist in this intimate association with the threads, but they soon lose their connection, increase rapidly in number and size, and come to lie close to the periphery of the vesicle. O. Schultze ('87) regards the increase in the number of nucleoli as due to division of those first formed, but he does not raise the important question as to how the first nucleoli originate. My own observations have led me to conclude that the nucleoli never multiply by division. I have repeatedly sought in vain, both in fresh eggs and in sections, for nucleoli in the act of fission. Schultze states, in support of his view (p. 195), that the nucleoli in very 
young eggs somewhat surpass in size those in slightly advanced stages. I have not found this to be the case in Diemyctylus In a germinal vesicle some $60 \mu$ in diameter and containing 199 nucleoli, the larger nucleoli measured from $\mathrm{I} \mu$ to $3 \mu$, the latter climension being never exceeded. A germinal vesicle about $9 \circ \mu$ in diameter contained about 442 nucleoli, the larger of which measured $3 \mu$ to $4 \mu$, while another vesicle $\mathrm{I} 3 \mathrm{I} \mu$ in diameter contained II 23 nucleoli of about $4 \mu$. The preponderance of large nucleoli is, if anywhere, on the side of the large eggs. Furthermore, if multiplication of the nucleoli by division were the ordinary occurrence, we might expect to find a certain uniformity in the size of these bodies, and a certain critical bulk, so to speak, at which division takes place. This is not so, but on the contrary, the nucleoli attain their maximum size shortly before their centripetal movement, which is just the condition that might be anticipated if we assumed a steady development and growth from the beginning. It is, moreover, not difficult, particularly in the early stages, when the number of nucleoli increases most rapidly, to find all gradations from the largest to the smallest, the smallest being indistinguishable from the more conspicuous granules in the threads. These facts would lead to the suspicion that the origin of the nucleoli is in some way intimately associated with the chromatin threads, that in fact the larger granules of the threads, stich as seen in Fig. I4, break loose from the threads and pass over into true nucleoli. I incline to believe that such is the case. Leydig ('88) holds a similar view as to the origin of the nucleoli in Triton tacniatus: ". . . in der Mitte des Keimbläschens ein zartes, dichtes Reticulum sichtbar ist, dessen Knotenpunkte von Keimflecken der kleinsten Form nicht zu unterscheiden sind, so dass ein Uebergang der einen in die andern unmöglich geleugnet werden kann (Fig. 94)." If the nucleoli in the growing egg thus arise from chromatin threads, ic strengthens the probability of a like origin for the first-born nucleoli.

Nucleoli are often said to arise as "much-thickened knots of the network of threads." I cannot regard such an expression as appropriate in the present instance, since there is no true "network," and since the designation of the young nucleolus 
as a "knot" is not particularly descriptive, as a glance at my figures will suffice to show.

At the time when the egg reaches nearly its full size, when the yolk is formed and the yolk-nuclei have attained their maximum complexity, when the nucleoli are largest and most numerous, there begins that remarkable centripetal march of the nucleoli which foreshadows their speedy disintegration. The first sign of this retrogressive movement is the peculiar appearance of the nucleoli while still at the periphery. They stain feebly and very unevenly, their outlines display the greatest roughness and irregularity and they are plainly in every respect experiencing degenerative change (see Fig. 16, Pl. XVI). The centripetal movement is not simultaneous on the part of all nucleoli. Some are to be found at the periphery while others are in the last stages of dissolution in the center. They usually straggle severally to the center and there fall apart, as shown in Fig. I 5, Pl. XVI, where several nucleoli are seen disintegrating en route. Subsequent stages are well shown by Schultze ('87) in Figs. 20 and 23.

I must strongly dissent from certain of Schultze's conclusions as to the fate of the nucleolar substance. After describing the disintegration of the nucleoli into small granules he adds: "Man überzeugt sich, dass die Körnchen, die ich jetzt Mikrosomen nennen darf, allmählich zur Erzeugung eines Fadenknäuels zusammentreten, der also nicht aus einem präformirten Kerngeriust entsteht, sondern sich direkt aus den winzigen Keimkörperchen herausbildet." (p. I98.) I cannot agree with Schultze that the granules from the disintegrating nucleoli go to build up the "Fadenknäuel." The granules resulting from the nucleolar dissolution are simply strewn throughout the central part of the vesicle (Fig. I 5), and to the best of my observation ultimately mix with the rest of the egg substance at the time of the dissipation of the germinal vesicle. There is indeed no preformed "nuclear network," but since there never is a very clear network in the amphibian egg this is beside the question. There are, however, chromatin threads or chromosomes distinctly traceable through the whole history of the germinal vesicle. These preformed chromosomes seem to have been overlooked 
by Schultze. They do not arise from the disintegration of the nucleoli, but exist before the nucleoli begin to migrate centrewards (see Fig. I6, Pl. XVI). To the consideration of these important structures we must now turn.

Chromatin threads or Chromosomes. - I have hitherto referred to the filamentous chromatin as if it were in the form of isolated and independent elements. I freely admit that no convincing proof can be adduced to show that there actually exist distinct individual chromosomes rather than a single looped and twisted skein. I have found it impossible to determine this point, but I am so far influenced by the appearances observed in my sections as to incline to the belief that the filamentous chromatin is in the form of detached threads rather than in one continuous coil. I shall accordingly use the term "chromosomes," premising, however, that I do so rather for the sake of convenience than for any strong belief in its absolute accordance with the facts.

In sections through young eggs the chromosomes present the appearance shown in Figs. 4 and I4. They are strings of cohering granules of varying dimensions, and in the youngest eggs these granules are indistinguishable from the small nucleoli. I have sometimes found threads somewhat resembling those figured by Flemming ('82) in Siredon (p. I 34) though his figure of the egg of Rana (Fig. 78, Pl. V) is much closer to the usual appearance in the egg of the newt. Leydig ('88) has given for Triton (Fig. 93, Pl. XV) a representation very much like what I have observed in Diemyctylus except in the disposition of the threads. I have never seen chromosomes of the curious filamentous structure found by Rückert ('92) in the Selachian egg; the chomosomes of Dicmyctylus are always of a loosely granular texture. I have also never observed any association of the chromosomes - if such they be - in pairs in the highly suggestive manner figured by Kastschenko ('90) and Rückert ('92) in the Selachian egg.

The most striking difference between the chromosomes of the stage shown in Fig. 4 and those of Fig. I 6 is in the relative susceptibility to stain. The young chromosomes stain comparatively readily and are in consequence easily detected. They subsequently appear to undergo a gradual change in their 
stainability, and stain more and more feebly until it is only with the closest scrutiny that they can be observed at all (Fig. I6). This fact, I think, accounts for the overlooking of these structures by Schultze. The apparent feeble reaction of the older chromosomes to stains may be due either to chemical change in the chromatic substance or to the mechanical separation of the chromatin granules. About the time that the nucleoli break up, the chromosomes become more deeply stained; whether this indıcates a welding together of the chromosome substance or a different molecular constitution I must regard as an open question. The problem of the number of chromosomes at different stages in the history of the ovarian egg, which has been raised by the interesting researches of Rückert ('92) on Selachians, may safely be left until the actual existence of independent elements is definitively demonstrated.

General considerations. - The history of the germinal vesicle and its parts, as thus far outlined, brings us to an estimate of the general significance of the phenomena observed. It is a time-honored hypothesis that the substance of the egg-cell of every organism is differentiated into two radically unlike protoplasmic parts, into a part concerned wholly with the transmission of hereditary qualities, and a part occupied solely with the development of the egg-cell. The principal bearer of the hereditary tendencies is considered by many to be the nuclear chromatin network, composed of the socalled Idants of Weismann, which are handed down from generation to generation practically unchanged by somatic influences.

There is not this consensus of opinion, however, regarding the seat of the ovogenetic or histogenetic element. This ovogenetic element has been variously regarded as resident in the yolk-nuclei, as an attribute of the cytoplasm itself and as inextricably mingled with the germ plasm. The now abandoned hypothesis according to which the ovogenetic substance was thought to be sundered from close association with the germ plasm and then expelled as the first polar globule is too familiar to need comment. A more recent view is that put forth by 
Rückert ('92) who finds a remarkable increase in bulk of the chromosomes in the Selachian egg during the growth of the egg, and an equally striking decrease premonitory of vesicular dissolution. Rückert considers this general atrophy of the chromosomes as due to the withdrawal of the ovogenetic or "somatic" substance. The chromosomic material remaining after the dissolution of the ovogenetic portion corresponds to Weismann's Keimplasma.

Ruckert draws an interesting comparison between the phenomena observed by him in the Selachian egg and the nuclear phenomena discovered by Maupas and R. Hertwig in the infusoria ('92, p. I 34). In the behavior and functions of the infusorian macronuclei and micronuclei he sees a close analogy the phenomena displayed by the Selachian chromosomes.

While admitting that such an interpretation may perhaps hold for the Selachian egg I think that in the amphibian ovum a somewhat different explanation must be sought after. The chromosomes here undergo no extensive changes in bulk; the mucleoli, however, do increase onomously in number and sizc during the anabolic period of maturation. I therefore believe that in this case it is between the nucleoli and the macronucleus of infusoria that a comparison, if such a comparison have any value, can be most aptly drawn.

It is now well established, thanks to the brilliant researches of Maupas and Hertwig, that the infusorian micronucleus is the bearer of the hereditary tendencies while the macronucleus possesses a nutritive and regenerative significance. At the time of the conjugation of ciliate infusoria the macronucleus degenerates and totally disappears. The micronucleus takes part in conjugation, and the daughter micronuclei give birth to new macronuclei.

A close parallel to this series of events is found in the history of the amphibian nucleoli. (I) They arise if not from, at least in intimate connection with the chromatin threads, the presumable bearers of the germ plasm. (2) Their function is almost certainly one of nutrition. (3) When the nucleoli have ended their ovogenetic duties and the ovum is fully formed, they degenerate and are dissipated throughout the vesicular 
substance, taking no visible part in the process of fertilization. In all these respects the nucleoli resemble the infusorian macronucleus.

(I) It is universally admitted that cell nucleoli in general, even if they do not arise directly from the chromatin network, lie in the meshes of the chromatin coil and at their inception are always in the most intimate association with it. Many good observers insist that the nucleoli originate immediately from the substance of the chromatin threads, but on this point the evidence is still insufficient to produce conviction.

(2) The general functional significance of nucleoli is still very obscure, although many ingenious surmises on the matter have been advanced. Strasburger and Pfitzner, as is well known, regard the nucleolus as a place of storage of "reserve substance." On all sides there is a growing tendency to look at the nucleoli as concerned either in the storage or the elaboration of nutritive substance. In the amphibian egg, as we have seen, it is difficult to avoid regarding the nucleoli in this light. In a general way, also, it is true that the larger the egg, the larger the quantity of nucleolar substance, seeming to point to a direct ovogenetic relation. There is, on the whole, therefore, substantial reason for looking upon nucleoli, wherever found, as concerned in one way or another with the active metabolism (anabolism?) of the cell. The fact that different types of nucleolar-like bodies have been found by Carnoy and others does not militate against this view. Indeed, the behavior of the "plasmasomes" described by Ogata (83) which wander out into the cell and there become the so-called "Nebenkerne," playing an important part in the regeneration of the cell, confirms the essential similarity in function between these and other nucleoli. One may legitimately suppose that these bodies which behave thus differently towards stains - whether "karyosomes," "plasmasomes" or "hyalosomes" - are in different stages of nucleolar development, or even that a fundamental nucleolar substance has differentiated according to the metabolic needs of the cell and has assumed various allotropic forms. One is not constrained to regard these bodies as fundamentally unlike; the presumption may be rather the other way when we 
remember the sharp differences in chemical reaction dependent on apparently slight differences in chemical constitution.

(3) There is much greater unanimity of opinion concerning the fate of the nucleoli of the egg-cell than concerning either their origin or significance. The nucleoli always degenerate and disappear before the process of fertilization.

Thus in origin, function, and fate many of the bodies called nucleoli constantly suggest community of relationship with the infusorian macronucleus. We are, however, hardly at present in a position to know whether this resemblance is superficial or fundamental.

The interesting case brought forward by Rückert, and already touched upon, may be considered as consonant with the analogy just drawn. It may be supposed that the fluctuations in the bulk of the Selachian chromosomes are due to a certain proportion of ovogenetic (nucleolar?) substance remaining attached to the chromosomes and never becoming separated as true nucleoli. This modification of his view allows it to be brought into harmony with other ovogenetic observations. It is worthy of notice that Rückert observes and remarks upon the close parallelism of development between Selachian nucleoli and chromosomes.

The atrophy of the germinal vesicle and the formation of the polar bodies. - The principal changes that take place in the germinal vesicle before the egg leaves the ovary have been already described. The germinal vesicle in Fig. 15 has nearly reached the limit of the changes which it undergoes while the egg is still in the ovary. The oldest nuclear appearance that I have found in an ovarian egg very closely resembles that shown in Fig. I5, except that the chromosomes are slightly stouter and more distinct, and are massed together in the center, while at the same time the borders of the vesicle show an incipient invasion of yolk spheres. Between such an appearance and the well-defined maturation spindle, shown in Figs. I 8 and 2 I, I have found no intermediate stages, although I have made careful serial sections through a number of eggs showing a light spot externally and apparently just ready to break loose from the ovary. The transition is evidently an 
abrupt one. It seems likely that the vesicle remains for sometime on the verge of dissolution, and that the shock of separation from the ovary precipitates the sudden change. All the eggs that I have found, both in the body-cavity and in the oviducts, contain a completely formed spindle.

It is manifest, then, that in Dicmyctylus, at about the time the egg falls from the ovary into the body-cavity, the greater part of the germinal vesicle is distributed throughout the yolk. With a high power (Zeiss, $2 \mathrm{~mm}$. immersion) the débris of the vesicle can be easily recognized surrounding the maturation spindle near the upper pole of the egg. The semi-fluid nuclear sap containing minute granulcs lies between the yolk spheres, and in it are strewn fragments of half-digested nucleoli. In some cases a portion of the vesicular substance appears to ooze out upon the surface of the egg, where it has been described as the perivitellin by Hertwig, Schultze, and others. The perivitellin of the newt resembles the perivitellin of Siredon, as figured by Schultze (see Schultze, '87, Fig. 29). Schultze also recognized the remains of the nucleoli, -.. "kleine, kreisrunde Chromatinkörperchen, offenbar die Reste der nicht völlig gelösten Keimkörperchen."

This admitted fate of a portion of the nucleolar substance seems to me to indicate the fate of all. It does not appear to me probable that, as Schultze maintains, a part of the material of the nucleoli goes to form chromosomes while another part degenerates and is lost, but rather that all the nucleolar substance shares alike. Dissolution and dissipation seems the likely end of all the nucleoli, as it is here unquestionably the end of some.

Besides the disintegration of the vesicle, when the egg is loosed from the ovary, there is another highly important but very obscure change. This is the transformation of the chromosomes from numerous, long, thin, faintly staining threads to a few stout rods (Fig. I 8). I have not been able to discover how this welding of the chromosomic substance takes place. The change from the delicate filamentous structure to the massive compact one is apparently the work of a short time. There seems to be a reduction in the number of individual 
chromosomes during this process, but owing to the extreme difficulty of delimitation (see $\epsilon . g$. Fig. I5) this may be only apparent.

Coincident with this abrupt internal change there becomes visible on the upper pole of the egg the well-known "light spot" of amphibian ova, the so-called "Cicatricula" of Prévost and Dumas, the "Keimpunkt" of v. Baer and the "Fovea germinativa" of Max Schultze. This area has been figured for the axolotl egg by v. Bambeke ('70), and his figures resemble essentially the fovea of the newt. There is (Fig. 3) an outer ring of brown pigment shading off on the outside into the normal pigmentation of the upper pole, and on the inner side sharply defining the limits of the light area. This light area (cl. $s p$.) encloses within itself a small circular spot of still greater whiteness; in the middle of which is a minute dark spot. This superficial marking is usually found on all eggs taken from the body-cavity and oviducts, and persists for about two hours after the egg is laid. It then slowly disappears and the surface of the egg resumes its original uniformity.

The internal changes that give rise to this constant external appearance are in the main identical with those that have been described by O. Schultze in Siredon and other amphibia. The germinal vesicle towards the end of maturation slowly presses nearer to the periphery of the egg, and before the egg leaves the ovary the position of the vesicle is betrayed by the "light spot" due to contrast of the vesicle with the surrounding egg substance. The pigment and yolk are of course pushed to one side by the advancing vesicle. Then steps in the abrupt vesicular dissolution above described.

Sections through eggs from the body-cavity (Fig. 2I) show a well-formed spindle which often exhibits a striking accumulation of pigment at the two poles. The spindle itself is undoubtedly the basis of the small white spot seen in the midst of the light area (Fig. 3), while the pigment at the peripheral pole of the spindle causes the minute central point of black. The neighborhood of the spindle is occupied by the débris of the vesicle together with small invading yolk spheres. Except in immediate proximity to the spindle, pigment gran- 
ules are conspicuous by their absence, and this absence of pigment, or the presence of the vesicular débris, or both, unquestionably gives the appearance of the large light area (Fig. 3).

Schultze (l.c., p. 205) seems inclined to adopt the view that the absence of pigment in this region is due to the fact that the germinal vesicle once filled this area, and that, notwithstanding the vesicular atrophy, the pigment granules still remain pressed out in a ring. It does not seem to me, however, that this explanation, simple as it is, is quite satisfactory. Since yolk granules are found in considerable numbers throughout this region, one is tempted to ask, if the yolk granules have thus invaded the former site of the vesicle, why not pigment granules also? The mantle of pigment granules that often envelops the spindle, and is particularly dense at the two poles, is a partial answer to this question. It shows that pigment granules have entered the vesicular region along with the yolk spherules, and have been attracted to the close neighborhood of the spindle. The comparative lack of pigment in the surrounding territory may well be due in part to this concentration around the spindle. But this cannot account for all the phenomena. Shortly after the egg is laid the pigment begins to show a more even distribution over the upper hemisphere of the egg, and eventually regains its original uniformity of disposition. This takes place in a few hours. Now, since the white spot has in some cases remained practically unchanged for at least forty-eight hours, - as I shall show later - and since during all this time the outer ring of pigment has been forced to keep its distance, it cannot be mere lapse of time that brings about the redistribution of the pigment after the egg is laid. The principal events of the period that follows the deposition of the egg are changes in the nuclear substance (including by that phrase the whole spindle-chromosome mass), and the migration of the female pronucleus away from the periphery. Since the female pronucleus carries with it in this migration a comparatively insignificant amount of protoplasm, one is led to infer that it is either the nuclear metamorphosis or the nuclear 
migration that permits the rearrangement of the pigment on the surface of the egg. It is not therefore altogether unwarrantable to suppose that the disturbing influence of the nucleus may account in part at least for the existence and position of the outer pigment ring. After the nucleus leaves its peripheral position, but not before, the pigment becomes uniformly distributed over the surface. The nature of this repellant influence, if we choose to regard it as such, must for the present remain obscure. It is sufficient to remember that similar phenomena, viz., the attraction of small particles into close proximity to an object and the repulsion of other like particles to a distance, are not wholly unknown.

The massing of the pigment at the poles of the spindle would seem to indicate the presence there of attracting bodies, and I was therefore led to search quite carefully for centrosomes, but without success.

The spindle in all the eggs of this stage lies close against the periphery of the egg (Figs I 8-22). There is sometimes a slight depression in the surface of the egg at the bottom of which lies the spindle (Fig. 2I), but this would seem to be the exception rather than the rule.

The axis of the spindle in thirteen oviduct eggs was approximately radial; in two it was tangential. Schultze ('87) has advanced an ingenious explanation of this varying disposition of the spindle axis in the ripening eggs of Siredon. He considers in brief, "dass auch hier die abwechselnde Einstellung der Spindel kurz gesagt aus dem Kampfe zwischen dem karyokinetischen Gesetz und dem Gesetz der Kernstreckung hervorgeht." For a searching discussion of this interesting question I must refer to his analysis.

I am unable to determine with certainty from my preparations the precise time of expulsion of the first polar body, since I have not succeeded in discovering a polar body on the surface of the oviduct egg. There is, however, a certain amount of circumstantial evidence which appears to indicate that the first polar body may be formed while the eggs are in the upper portion of the oviduct. Eggs from the body-cavity and from the 
upper part of the oviduct exhibit the disposition of chromosomes seen in Figs. I 8 and $2 \mathrm{r}$. This must be taken as indicating the metakinetic separation of the chromosomes, and apparently foreshadows the speedy formation of a polar body. This view is strengthened by the fact that eggs in the lower part of the oviduct are all in the quiescent "equatorial plate" stage as shown in Fig. I9. In this condition they remain until after the egg is deposited and spermatozoa have entered. About one hour and a half to two hours after deposition the second polar body is expelled (Fig. 20). The minute size, of this body in the newt, as indicated in Fig. 20, is probably the reason for my failure to discover it after expulsion.

The eggs of the newt often remain in the oviducts unchanged for at least forty-eight hours. I have elsewhere stated that newts freshly captured from the ponds during the months of May and June are almost invariably found to have eggs in the oviducts. These individuals when brought to the laboratory and placed in aquaria do not as a rule deposit their eggs until the second day after the capture; the eggs thus tardily deposited develop normally. The number of eggs that is usually laid in the course of twenty-four hours (sce p. 276) seems to indicate that at least twenty-four hours is required for the passage of an egg down the oviduct. Not more than ten or twelve eggs are found in an oviduct at one time, even in a large female. The formation of the protecting membrane takes place along the whole length of the oviduct, but is most active in the middle and lower thirds.

NoTE. - Since finishing this paper I have received Born's paper upon the maturation of the amphibian ovum (Die Reifung des Amphibieneies und die Befruchtung unreifer Eier bei Triton tæniatus, Anat. Anz., VII., I892, p. 772). Born's account of the continuity of the chromatin filaments fully corroborates what I have found in Diemyctylus, and renders completely untenable the view that the "skein" in the older eggs is constructed out of fragments of disintegrated nucleoli.

The only mention of a yolk-nuclcus is on p. 777. Until Born certainly identifies this "finely granular, oval body" with the yolk-nucleus of other authors it would be unfair to criticise his singular statement that "in diesen Gebilden das Archoplasma und die Centrosomen des Keimbläschens zu suchen sind." 
Born finds that in Triton taniatus the first polar body is expelled while the egg is in the upper part of the oviduct. I had strongly suspected that this was the case in Diemyctylus (see p. 307), but was unable to present definite proof. Born's results on this important point furnish a welcome confirmation of my surmise.

I do not feel it necessary to enter at this time into a fuller discussion of the minor points of accord and discord between Born's results and my cwn..

\section{Fertilization.}

The fertilization of the egg takes place just before the egg is extruded. The spermatozoa, which have long been in waiting in the tubes of the receptaculum seminis, are either attracted from their resting-places by the passing egg or forced out by contraction of the surrounding muscles. I have made repeated and careful search for spermatozoa in the oviducts, but have never succeeded in finding one. Neither have I ever found in sections any indication that spermatozoa enter oviduct eggs, although eggs often lie for some time in the mouth of the oviducts. Fertilization, then, would secm to. take place only after the egg has left the oviduct and passed. into the cloaca.

It sometimes happens that non-fertilized eggs are dropped by females in captivity. It is an interesting fact that these: non-fertilized eggs are not deposited in a carefully prepared nest, but are dropped, apparently without concern, on the floor of the aquarium. Sometimes, but very rarely, an egg thus loosely dropped develops normally, showing that fertilization has taken place. The explanation of the dropping of non-fertilized eggs seems to be that in females with full oviducts, an egg is occasionally pressed into the cloaca by the mere elasticity of the oviduct walls and without the special cognizance of the newt. This egg then passes out like so much cxcreta without the performance of a voluntary act of oviposition. The fact that these eggs are, for the most part, unfertilized indicates an expulsion of spermatozoa from the receptacle during the normal process of egg-laying. This view is strengthened by the fact that the act of oviposition usually takes an appreciable time, often eight or ten minutes, pointing to essential accompaniments of the mere process of extru- 
sion. There is good reason to think, then, that during the process of oviposition (see p. 277) the egg passes from the oviduct into the cloaca, where it is fertilized by spermatozoa pressed out of the receptacle, and thence is extruded along with a quantity of gelatinous secretion that glues together the leaves of the "nest." All of these actions are undoubtedly to a certain degree coörclinated under voluntary control. The occasional fertilization of one of the excreted eggs is probably due to the chance presence of a stray spermatozoon in the cloaca.

Since it is true, then, that the fertilization of the egg does not take place until the egg reaches the cloaca, the spermatozoa which strive for entrance there find themselves confronted with a formidable egg-membrane. The consistency of this membrane can be adequately realized only through repeated attempts to remove it from the living egg. So improbable did it appear to me that spermatozoa should be able to pierce this dense and leathery covering, that I sought long and carefully for a micropylar opening. The search, however, was fruitless, and this negative result, together with the fact that spermatozoa ordinarily penetrate the egg at different and widely separated points, oblige me to admit, though somewhat reluctantly, the probability that spermatozoa somehow succeed in making their way through the membrane.

The points of entrance of the spermatozoa may be seen as slightly depressed, pigmented areas on the surface of the living egg freed from its membrane, one to two hours after oviposition (Fig. 6). There are several of these points, as a rule, indicating the penetration of several spermatozoa, an inference which, as we shall see, is fully sustained by the evidence from sections. There is no fixed and predetermined point of entrance; the spermatozoa may invade the egg in the neighborhood of the "light spot" (Fig. 6), or they may force an entrance near the equator of the egg. Most frequently they enter the upper (pigmented) pole, but I have several times observed them entering the lower hemisphere. Roux ('87, p. 174) has established a similar indeterminateness in the point of penetration of the spermatozoa of Rana. 
The progress and maturation of the spermatozoa after they enter the egg may be best studied by sections through eggs from two to five hours old. The advance of the spermatozoon into the egg is signalized by the often described streak of pigment (Fig. 23C). This pigment streak, though it is not so prominent in the egg of the newt as in more deeply pigmented eggs, enables the path of the spermatozoon after entrance to be easily traced. It has been thought by some observers (see $e . g$. Hertwig, '77, p. 49) that the pigment is mechanically carried in from the cortical layer by the onward movement of the spermatozoon. While this may be in part true, there is another factor that undoubtedly assists in the production of the pigment streak. The eggs of the newt when viewed from the surface show the points of entrance of the spermatozoa each distinctly marked by a spot of pigment. The pigment accumulation at these points forces one to conclude that the male element exerts an attractive influence upon pigment granules comparable to that shown by the poles of the maturation spindle (Fig. $2 \mathrm{I}$ ). This attractive force appears to diminish as the sperm penetrates deeper into the egg, and the pigment granules discarded along the way then form the familiar pigment trail. There is, therefore, some force connected with both male and female elements that, in certain stages, attracts pigment granules; this force at other stages appears to lapse into quiesence.

There frequently arises a considerable accumulation of a semi-fluid reticular substance (protoplasm ?) around the head of the male element. This accumulation often assumes the form of a mushroom, showing crescentic in sections (Figs. $23 \mathrm{~B}, 23 \mathrm{C}$ ). The head of the sperm occupies the middle of this area, and the whole effect is such as almost to convey the impression that the yolk granules have been driven out of this region by movements of the spermatozoon. I am loth, however, to believe that such is the case, since there is good reason to think that the active movements of the sperm cease after it penetrates the egg. Occasionally a faint filament stretches off behind into the pigment streak and strongly suggests the presence of the tail of the spermatozoon (Fig. $23 \mathrm{~B}, 23 \mathrm{C}$ ). I am unable, however, to identify it certainly as such. It is not to be seen when 
the spermatozoon has penetrated some distance into the egg substance.

I have not succeeded in discovering the earliest stages in the metamorphosis of the sperm-head into the male pronucleus. When the spermatozoon first enters the egg (Figs. 23B, 23C) the head does not appear to be sharply defined, and the earliest stage at which $I$ have been able to recognize a well-clifferentiated portion is shown in Fig. 23D. Here the head is already far on the way towards becoming a true pronucleus. The most obvious point of difference between this stage and the mature pronucleus shown in Fig. $23 \mathrm{~A}$ is one of size. This is somewhat exaggerated by the difference in magnification of the two figures, but even making the necessary deduction for the difference in magnification the increase in size will be seen to be considerable, and amounts to at least a doubling in diameter. Sometimes during: the maturation of the male element the yolk granules in the neighborhood assume a radial arrangement, but this astral phenomenon is not of invariable or indeed frequent occurrence. The membrane of the pronucleus in the early stages is less distinct than it afterward becomes ( $c f$. Figs. 23A and 23 D).

My friend Dr. Watasé ('92) has determined by Auerbach's method of differential staining that the sperm-nucleus of the newt reacts differently at different stages of its maturation period. When it first enters the egg it is, like the original sperm-head, strongly cyanophilous, but the reaction gradually alters until, just before union with the female pronucleus, both male and female pronuclei stain identically.

The rapidity of movement of the male element when once inside the egg does not seem to be great. The spermatozoa enter the egg from one to two hours after deposition, and although they sometimes enter in close proximity to the female element (Fig. 6), union does not usually occur until from four to six hours later. It is obvious that the fallacy incident to all studies upon preserved eggs lurks in this estimate of rapidity of movement. Since, however, Fig. $23 \mathrm{C}$ shows a spermatozoon in an egg two hours old, and since Fig. ${ }_{23} \mathrm{D}$ is from an egg four hours old there would seem to be a fair basis for the assumption of slow penetration. It is of course likely that the 
male and female elements busy themselves during this period more in preparation for union than in actual movement. It is even fair to suppose that speedier metamorphosis of the nuclei would imply - or, perhaps, cause - greater rapidity of movement. This indeed is indicated by the course of the phenomena in the frog's egg where the course of events is more rapid. The hindering effect of the yolk must be practically the same in both cases, and one is justified therefore in regarding the slower movement of the male element in the newt's egg as the expression of a slower maturation of that element. In other words it is not the external obstacles, but the internal changes that determine the rate at which the two pronuclei approach each other.

The path taken by the sperm is similar to that described by Roux ('87) for the frog's ovum. The spermatozoon moves at first centripetally, describing the "penetration-path," and later describing the "copulation-path," curves more or less abruptly towards the female pronucleus. The initial change from the centripetal to the nucleopetal direction is shown in Figs. ${ }_{23} \mathrm{C}$ and $23 \mathrm{D}$. It is impossible not to agree with those who hold that this change in direction is due to some sort of nuclear attraction.

The female element, which is the objective point of the male pronucleus and is hence the cause of the change of direction of the latter, is by no means a mere inactive spectator of the entrance of the spermatozoon. About two hours after the egg is laid the polar body (second?) is expelled (Fig. 20). It is clear that this expulsion of the polar body is caused directly by the penetration of the sperm into the egg, since before this event the female element has remained perfectly passive, it may be for upwards of forty-eight hours. The nature of this telepathic influence is far from clear. After this event the female pronucleus is formed by a series of changes which I have not been able to trace out completely, but which appear to be essentially parallel to those of the sperm. Indeed I have been in most cases unable to distinguish between the male and female pronucleus after the formation of the latter. This is owing partly to the fact that the male pronuclei are usually numerous, partly 
to the fact that in the newt's egg only a slight quantity of pigment attends the path of the sperm, but chiefly to tine absence of any essential divergence in structure between the two pronuclei. It occasionally happens that one may pick out from the rest a pronucleus which is perceptibly larger or is surrounded by a greater quantity of protoplasm than the others, and $I$ have naturally been inclined to regard such a body as the female element. This, it will be recognized, is a very inadequate basis for such identification, and careful examination of all the pronuclei found in an egg has served only to convince me more strongly of the unsatisfactory nature of such a criterion.

The union of the two pronuclei takes place ordinarily about six to eight hours after the egg is laid. The place of meeting does not seem to be constant or predetermined. It is never in the geometric center of the egg, but is nearer the upper pole, and is usually, so far as I have been able to determine, in the neighborhood of the position occupied by the germinal vesicle before dissolution. The general phenomena attending the union of the pronuclei are substantially such as described by Hertwig ('77). The pronuclei that I have figured in Fig. 23A present a typical appearance. The inner one $(f)$ may perhaps be regarded as more probably the female since it is surrounded by the larger quantity of protoplasmic substance, and since the other $(m)$ has apparently just impinged upon it from the side. Such identification, however, is based on pure analogy and on no sure recognition-marks. The question here arises as to whether the female pronucleus exercises any power of selection from among the several suitors at her disposal or whether it is a mere matter of proximity that determines which male nucleus shall unite with the female. I may here state, what to some will doubtless seem superfluous, that I have never seen any evidence whatever that more than one male element unites with the female. Why the one individual so favored should be preferred above his fellows is somewhat problematical. It is obvious, however, that other things, such as proximity, etc., being equal, the sperm first entering would have the advantage. Its earlier maturation would bring about a reciprocal movement of both male and female which would soon 
place it ahead of all competition. Proximity and order of entrance are undoubtedly the two factors that determine the success of the sperm's quest.

Polyspermy. - I have already mentioned that several spermatozoa normally enter the egg of the newt. I may now state that I have sectioned twenty eggs from two to ten hours old and found in every egg superfluous male elements. The number of these varied from one to thirteen and was in most cases from six to eight. If it be objected (Born, Roux, Hertwig) that such polyspermy indicates pathological conditions, I may reply that these twenty eggs were all laid in a normal way, by different females and at different times; that abnormalities are very rare in newt development and that such a succession of non-developing or abnormally developing eggs would in my experience be unprecedented; and finally that I have in the living egg watched several spermatozoa enter the upper pole and normal development succeed in every case. There is thus every reason for regarding such physiological polyspermy in the newt as a natural, normal, and, in fact, usual occurrence.

What now is the further history of these superfluous spermatozoa which normally enter the egg of the newt? In the first place it is to be remarked that these accessory sperm nuclei (Nebenspermakerne) undergo a progressive development after their entrance. They increase in size, acquire a doublecontoured membrane, and show precisely the same affinity for stains as the male element that fuses with the female pronucleus. They are in all objective respects quite as competent aspirants to union with the latter as is the male nucleus (Hauptspermakern) actually honored. They owe their non-preferment not to any intrinsic inferiority, but to the time and place at which they entered the egg. These accessory sperm nuclei are most numerous in the region of the upper pole, but are quite often found stranded among the large yolk spheres of the lower hemisphere. In the latter case they are usually near to the periphery of the egg.

The accessory sperm nuclei ultimately degenerate. Shortly after the fusion of the two chief pronuclei the superfluous male 
elements begin to show signs of degenerative change, and in eggs ten hours old - just before the beginning of the first cleavage plane - they are in a condition of well-marked atrophy. This is evinced by the disappearance of the membrane and by the mixing of the chromatin through the egg substance. I have been able to identify degenerating accessory nuclei in the four-cell stage, but not beyond.

v. Bambeke (70) was one of the first to affirm that several spermatozoa normally entered the amphibian egg, but his statements were on the whole regarded as relating to abnormal conditions, and were not given the credence to which I think they were entitled. Since his observations were made upon the eggs of certain Urodela, and since none of his critics have repeated his observations on these particular species, but have reasoned themselves into incredulity solely through their own negative results upon the eggs of other animals, there seems no good reason for refusing our acceptance of v. Bambeke's observation. Negative observations upon the eggs of one animal hardly furnish an adequate basis for scepticism regarding positive phenomena in the eggs of related animals. Kupffer ('82) also has affirmed the normal entrance of several spermatozoa into the amphibian egg.

Physiological polyspermy has been observed, moreover, in the eggs of other vertebrates. Two of the most important cases I may briefly mention. Rückert ('91, '92 ${ }^{\mathbf{a}}, \mathbf{~} \mathbf{2}^{\mathbf{b}}$ ) has described some remarkable phenomena of this character in the eggs of Selachians (Pristiunus, Torpedo). A number of spermatozoa normally enter the egg, develop like the chief male pronucleus, and, at the formation of the first cleavage nucleus, divide caryokinetically, and give rise, in part, at least, to the parablast nuclei, or "Merocytenkerne"! These Merocytenkerne which arise thus independently from accessory spermatozoa are distinguished from the nuclei of the "Furchungskern" by a smaller number of chromosomes - " höchstens die Hälfte"! "Alle Merocytenkerne der jungen Furchungstadien, welche eine reduzierte Zahl von Chromosomen besitzen, sind Abkömmlinge von Spermaköpfen. (Rückert, '92 ${ }^{\text {b }}$, p. 329.) 
Polyspermy has been described also by Oppel ('92) in the reptilian egg (Anguis, Tropidonotus). His results agree strikingly with those of Rückert, although presenting many interesting points of difference. Here, as in the Selachians, a number of spermatozoa normally penetrate the egg. They develop into full-fledged sperm nuclei which divide caryokinetically, though very sluggishly and irregularly, and soon abort.

There is, hence, wide variation in the phenomena of fertilization among vertebrates. (I) Only a single spermatozoon normally enters the egg [Teleost (Trout), Böhm; Amphibia (Rana), Born, Roux]. (2) Many spermatozoa normally enter the egg, in which case they may (a) develop into nuclei which divide caryokinetically and regularly (Selachians, Rückert); or $(b)$ they develop into nuclei which divide slowly and with many abnormalities, and soon degenerate (Reptilia, Oppel); or $(c)$ thcy develop into nuclei which speedily degenerate without undergoing division (Diemyctylus).

One thing is certain : such physiological polyspermy as has been described here is a usual occurrence in the eggs of many vertebrates. This establishes the important fact that the mere entrance of several spermatozoa into an ovum exerts no injurious influence upon development. This being true, it follows that the more frequent case of the admission of only a single sperm is probably to be regarded as due to the conditions of nuclear attraction rather than to any necessity for barring the way against superfluous spermatozoa. It is not that an excess of spermatozoa is harmful, but that the female nucleus is satisfied, as it were, with the entrance of one, and no longer acts so attractively upon those outside. The fact that several spermatozoa enter an egg which has been weakened by rough treatment or overripeness shows that the internal conditions of the egg cell have been altered, but shows nothing more. The abnormal development that follows cannot be regarded as purely the result of the superfertilization, but both events, the abnormal development as well as the entrance of several spermatozoa, are direct consequences of the internal disturbances in the egg. The normal 
entrance of a varying number of spermatozoa into an egg merely indicates unessential variations in the intensity and duration of nuclear attraction.

\section{Cleavage. ${ }^{1}$}

It is not difficult to obtain the egg of the newt immediately after the female has deposited it, and the order of appearance of the cleavage planes can then be accurately timed. I have preferred this mode of procedure to artificial fertilization since in this way the reproach of departure from the normal is not incurred.

The first cleavage plane begins from ten to twelve hours after the egg is laid. The furrow is vertical and divides the egg into two nearly equivalent halves, but usually falls more or less to one side of the exact mid line (Fig. 24, Pl. XVII). The furrow reaches the lower pole forty-five to sixty minutes after it first becomes visible at the top of the egs.

The second furrow is likewise vertical, and usually cuts the first at right angles near the mid-line, thus dividing the egg into four equivalent portions (Fig. 25). The second furrow appears from one and a half to two hours after the beginning of the first, and cuts its way to the lower pole with the same rapidity as the first.

With the completion of the second furrow all consistent regularity is at an end. The third furrow is often horizontal, but is very variable in position and is usually differently disposed in each of the four quadrants. Frequently it can be designated as equatorial only by courtesy, and occasionally it is distinctly vertical. This latter important fact $\mathrm{I}$ hope to bring out more clearly presently.

The point that I wish to touch on first is the great irregularity in the early cleavage stages. I have made a careful study of a large number of preserved eggs, and have depicted some of these in Figs. 26 to 32, P1. XVII. These figures con-

\footnotetext{
${ }^{1}$ I should here state that I reserve a more detailed consideration of the facts and significance of cleavage for a joint paper soon to appear by Mr. A. C. Eycleshymer and myself.
} 
sist of camera drawings of eggs seen in different positions. Each cell has its own individual number in order to facilitate recognition in the different points of view. The eggs chosen for this study were those especially favorable specimens which permitted identification of the first two cleavage planes. They are therefore to be regarded as more regular than the great majority of newts' eggs, since in most cases the first two planes cannot be recognized with any fair degree of certainty. In the eggs $I$ have chosen to represent there is a minimum of uncertainty. The lines indicating the first two planes are printed more heavily than are the others. Since the magnification of all figures on this plate is the same, the series from Fig. 26 to Fig. 32 serves to illustrate the considerable variation in size of the newt's egg. The size appears to be in the main dependent on the size of the female, the larger individual as a rule depositing the larger egg.

Figs. 26A-26D represent an egg of eight cells seen in different positions. $26 \mathrm{~A}$ is a view from the upper pole, $26 \mathrm{~B}$ and $26 \mathrm{C}$ are views from the side, and $26 \mathrm{D}$ is from the bottom of the egg. The general disposition of the cells is very remote from the usual eight-cell stage, one cell-3-extending all the way from the upper to the lower pole. Figs. 27 A$27 \mathrm{D}$ are views of an egg of a more advanced stage, $27 \mathrm{~A}$ and $27 \mathrm{D}$ being respectively the upper and lower poles. The two upper right hand octants, 3-4 and 5-6, have divided in diagram fashion from the intersection of the first two planes, but the other two, I-7 and 2-8, have divided at very different angles. Only one of the lower pole cells (Fig. 27 C, 9-12) has begun to divide. Figs. 28A-28D show a still wider departure from the orthodox type of cleavage. The upper pole (28A) presents a far from regular appearance. Figs. $29 \mathrm{~A}^{1}-29 \mathrm{D}$ picture the most regular egg of this stage that I was able to find. Even here the lines of the third vertical do not start from the intersection of the first and second planes. Figs. $30 \mathrm{~A}-32 \mathrm{~B}$ illustrate top and bottom views of three eggs in advanced stages of

1 The upper pole of this egg bears a close resemblance to the egg figured by Rauber ('83) in Fig. 35, Pl. XII. 
cleavage. The total absence of any regularity in the arrangement of the cells is the most conspicuous feature.

It cannot reasonably be held, I think, that these eggs depart from the "normal" or the "type." They fairly represent the average and common course of cleavage in the newt, and would undoubtedly have resulted in normal development. I am convinced of the trith of this latter assertion through careful following out of a large number of living eggs.

The difficulty of following the cleavage in the egg of the newt is much enhanced by the opacity of the enveloping $\mathrm{mcm}$ brane. I have, therefore, usually removed the egg from the membrane soon after deposition. The removal of the membrane is accomplished with sharp needles and fine scissors, but is attended with considerable difficulty, and often results, even with the best of care, in the destruction of the egg. I have succeeded, however, after some practice, in cxtricating without injury a number of eggs and in following their subsequent development.

Firs. $33 \mathrm{~A}-33 \mathrm{~F}$ illustrate successive stages in the development of a living egg. Fig. 33A shows the upper pole at the beginning of the third set of cleavage furrows. These furrows appeared in this egg at the time when the "equatorial " plane was normally due, and must hence be regarded as "homologous" with the usual "first equatorial plane" of the amphibian egg. Fig. $33 \mathrm{~B}$ is taken ten minutes later and exhibits an interesting and remarkable bilaterality. The two furrows on the left have united near the equator of the egg, and, cxcept for the unusual nearness of their proximal ends to the middle of the upper pole, would be regarded as part of a typical equatorial. The two furrows in the right half of the egg, on the contrary, cut down to a point near the middle of the lower pole, as is shown by the aid of an underlying plane mirror (Fig. 33C). By comparison of these views of the upper and lower poles it is clearly seen that in one half of this egg the third cleavage plane is an undoubted vertical, while in the other half it is a dubious equatorial. The fourth rhythmical nuclear division cleaves the egg into the cells seen in Fig. 33D. Comparison with Fig. $33 \mathrm{C}$ will show the distortion of the earlier cleavage 
lines, and this distortion is carried still further by the next set of furrows (Fig. 33F). Fig. $33 \mathrm{E}$ portrays the lower pole of the stage shown in $33 \mathrm{D}$ and emphasizes the truly vertical character of the two furrows in the right half, which have here advanced so that they strike the center of the lower pole ; the equatorial tendency of the furrows in the other half of the egg is also confirmed. This egg developed into a perfectly normal embryo, with no visible deviation from the normal course of development.

I may here anticipate the forthcoming paper by Mr. Eycleshymer and myself so far as to state that we have convincing evidence that the whole third set of cleavage furrows in the amphibian egg may at times be vertical instead of horizontal and yet result in normal development. This fact has obvious and important bearings upon the question as to the "homologies" in amphibian and teleostean cleavage.

Axis of the Embryo, etc. - The relation of the first cleavage plane to the axis of the embryo is a point of some interest, although in the light of recent cytogenetic studies it cannot be held to be a matter of such vital importance as was at one time supposed. The egg of the newt, as I have stated elsewhere, is enclosed at the time of deposition in an oval, thick-walled membrane. The egg thus enveloped has been submitted while in the oviducts to such compression that for several hours after it is laid it is very much elongated in the direction of the long axis of the capsule. The long diameter of the egg at this time is often double the transverse diameter. Before the formation of the first cleavage plane the egg resumes its spherical form. The first cleavage plane invariably passes through the egg at right angles to the axis of the capsule and therefore at right angles to the direction in which the egg was elongated by compression. If the egg be left undisturbed in its capsule it adheres to the bottom of the capsule so firmly that it may be turned bottom upwards without rotating. After repeated observation of the living egg, I am convinced that when the egg thus fixed remains undisturbed and under normal conditions, rotation cannot occur. By the direction of the convexity of the crescentic blastopore (Fig. 35) and while the form of the egg is 
still spherical the axis of the embryo is seen to lie in the long axis of the capsule, and hence at right angles to the first cleavage plane. There is usually variation, often amounting to as much as $45^{\circ}$ or $50^{\circ}$, but, in by far the great majority of the eggs I have examined, the axis of the embryo is approximately at right angles to the first plane of cleavage.

In the egg of the frog, as is well known from the researches of Newport, Pflüger, Roux and others, the direction of the axis of the embryo coincides with the first cleavage plane. Throughout the animal kingdom there can be discovered no constancy in the relation of first cleavage plane and embryonic axis. There are several well-established instances where, as in the frog's egg, the two planes coincide, and recently cases have multiplied where the opposite is true and the planes are at .right angles (Nereis, Wilson; Crepidula, Conklin ; Jera, McMurrich). Miss Clapp ('91) has shown that out of twenty-three embryos of Batrachus, three showed coincidence of the axis of the embryo with the first cleavage plane. "Fourteen of the embryos had the head directed towards the right of the first line of cleavage, the axis of the body being at an angle with the first cleavage plane of from $30^{\circ}$ to $70^{\circ}$. In the remaining six the head was to the left of the first cleavage plane, the angle varying as before." It is a plausible hypothesis that when planes and axes do coincide or cross at right angles it is because both are determined by the same external conditions and not necessarily because there is any causal nexus between the two. It is possible that the same external factors that determine that the first spindle shall lie in a certain axis determine also the direction of the embryonic axis.

The most recent work in experimental embryology seems to confirm this inference and to demonstrate that great stress cannot be laid upon the relations of early cleavage planes and embryonic axes. When we know that four perfect gastrulae of Amphioxus can be produced from the first four quadrants of the egg, there is no basis for regarding the direction of the first cleavage plane as a matter of supreme importance. The early variations in the position of the nuclei in the newt (Plate $\mathrm{XVII}$ ), and the irregalar torsions of the first cleavage planes 
(Fig. $33 \mathrm{~F}$ ) indicate sufficiently well that the early stages of cleavage do not, in this case, rigidly mark out the future development of the embryo. The course of embryonic development in some animals is not dependent on the position or indeed the existence of all the early cleavage nuclei. We are consequently led to the conclusion that the parts are not essential to the integrity of the whole, that indeed the whole may be deprived of some of its parts and yet remain the whole. There is no qualitative sorting out of nuclear substance in the early cleavage stages; on the contrary a large proportion of nuclear substance can be displaced or even sacrificed without impairing the individuality of the embryo, or rendering it incapable of normal development. Wilson ('92) in his brilliant research upon the celllineage of Nereis, reached the conclusion that "Blastomeres having precisely the same mode of origin and precisely the same spatial relations to the rest of the embryo are by no means necessarily equivalent, either physiologically or morphologically, and the early cleavage-stages in themselves have little morphological value" (p. 455). Such a conclusion, drawn from annelid cleavage where the cell formation follows definite lines and the differentiation of important organs is strikingly precocious, is certainly applicable with added stringency to the other extreme of amphibian cleavage where the initial cleavage stages exhibit as a rule chaotic irregularities and variations.

Turning now to quite a different question, let us ask why the first cleavage plane should fall as it does in any individual case. Why should the plane pass through any particular meridian rather than through any other?

In the newt the most interesting fact about the first cleavage plane is its determinateness. It cuts the egg invariably, so far as my observations go, at right angles to the long axis of the enveloping capsule. In removing the egg from the capsule I have unfortunately not been able to preserve the orientation of the egg, and so have not succeeded in determining whether the egg when freed from the capsule still cleaves as it would have done inside. This constancy of direction of the first cleavage plane in the encapsuled egrg puts an obstacle in the way of accepting for the newt the view that Roux has advanced for the 
frog, namely that the path of meeting of the male and female pronuclei defines the first plane of cleavage. In the newt we should have to suppose, to uphold this theory, that the pathway was always coincident with the median transverse axis of the capsule. Since the point of entrance of the spermatozoon is indeterminate this supposition of an invariable pathway of approach is not justified. Furthermore, since several spermatozoa normally enter the egg there are several pathways in different directions, and some of the spermatuzoa travel a greater distance through the egg-substance than does the spermatozoon that unites with the female pronucleus. The sundering of the egg-substance may therefore be of greater extent along the path of an unsuccessful sperm-nucleus than along that of the "Hauptspermakern." It is obvious, then, that Roux's explanation of the direction of the first cleavage plane, however valid it may be for the egg of the frog, does not admit of application to the egg of the newt, and that here we must seek for some determining cause other than the path taken by the male and female pronuclei

As regards Schultze's view that the first cleavage plane is determined by the position of the germinal vesicle in the unfertilized ovum I must agree with Roux in considering the evidence for such a view inadequate.

In the case of the newt the very tempting explanation suggests itself that the direction of the first cleavage plane is due to the compression and elongation to which the egg has been subjected in the oviduct. It may be legitimately maintained that the arrangement of the egg substance has been so affected by this compression that the first spindle can place itself with its long axis parallel to the elongated axis of the egg more readily than it can in any other axis. In other words the spindle takes the direction that it does because the egg has been clongated in that direction.

Another slightly different explanation of a similar mcchanical nature is perhaps still more plausible. The egg soon after it is laid resumes its spherical form and is then in close contact with the capsule on all sides except in the direction of the long axis of the capsule. In this direction there is 
room for expansion; on all other sides the egg is hemmed in and is sometimes slightly compressed, as in cases where the capsule is so narrow as not to permit the egg fully to regain its spherical form. It is a curious coincidence, if nothing more, that the expansion of the ego incident upon the first cleavage should occur in just that direction in which it is most free to expand, that in other words the spindle takes up that position in which it can act most freely.

I am inclined to accept provisionally some such mechanical interpretation of the determinateness of direction of the first cleavage plane in the newt's egg. I do this the more readily since the effect of pressure in influencing the direction of cleavage planes is well known through the researches of Pfüger, Roux, Dricsch, and others. Roux's experiment of elongating frogs' eggs by compression in a narrow glass tube showed that such elongated eggs divided at right angles to their long axis, a fact that bears directly upon the case in hand.

By attributing the direction of the first cleavage plane to Sachs' law I do not in the least wish to be considered as implying that in the eggs of some animals other causes may not often take the place of pressure as a determining factor and may indced override it. I wish simply to state my belief that mechanical compression operates as the determinant of the direction of the first cleavage plane in the newt.

If we admit, as I think we are bound to do, that the earliest cleavage stages of these cggs have little or no morphological significance then I see no escape from the conclusion that they must depend on environmental or mechanical causes of one sort or another. Precocious differentiation may invest the early cleavage-stages of some eggs with a factitious significance. In others the early spindles may change the direction of their axes under the influence of various slight mechanical causes.

\section{Formation of the Blastopore.}

Technique. - The difficulty of extricating the living egg uninjured from the membrane has been so great that $I$ have as a rule preferred to kill the egg while it was still in the envelopes. 
This has not only saved much time, but has given me very satisfactory results for all studies of preserved specimens. I have found the most satisfactory killing agents to be Perenyi's fluid and the picro-sulphuric mixture of Kleinenberg, particularly the former, which I have come to use almost exclusively. The eggs at the desired stages are thrown into Perenyi for 24 to 48 hours, and then removed to a solution of hypochlorite of sodium (Eau de Labarraque), which so softens the membrane that it may easily be teazed off with needles. I have usially found it necessary to leave the eggs in the Labarraque for at least four to five minutes, in order to affect the membrane sufficiently. The eggs must be watched carefully during their stay in the hypochlorite, since both the strength of the commercial fluid and the resistance of the membrane vary widely; over-exposure to the action of the fluid renders the egg valueless. When the process of membrane softening has gone far enough - a point that only experience can determine - the hypochlorite is decanted and the eggs are very carefully washed with distilled water. After repeated washings the membrane is removed with needles, and the eggs are then transferred to 70 per cent. alcohol, where, after a few washings, they remain until wanted for examination. In this way I have obtained excellent specimens, which stain without difficulty and cut smoothly in paraffine. Eggs killed with the picro-sulphuric mixture are better for surface study, but are apt to be rather brittle for sectioning.

I have used for staining in toto chiefly borax carmine and Czokor's alum cochineal, both of which have given very satisfactory results.

For the surface study of preserved eggs I have used to advantage a background of white paraffine, in a hollow of which the egg lies, covered with 95 per cent. alcohol and lighted by direct sunlight with the aid of a condenser. By this method, which is substantially that followed by Erlanger ('89, p. 240), the surface of the egg may be exhaustively studied, and camera drawings made of all the external features.

I have relied not so much, however, upon the examination of preserved eggs as upon the following out of the surface 
changes in the living egg. Despite the considerable difficulty of removing the membrane I have succeeded in a number of cases in performing this operation, and in tracing the external changes in the egg thus freed. The development of such eggs is normal, and the time of appearance of the different external features is the same as in eggs on which the membrane is allowed to remain. The first stages of the formation of the blastopore are best observed with the aid of a plane mirror placed underneath the flat-bottomed watch-glass in which the egg rests. The reflected image of the lower pole may be easily studied with the dissecting microscope and the successive changes accurately determined. For the study of the blastopore when it shifts to the side, I place the egg in a thin-walled glass chamber in which it can be examined with the microscope-tube in a horizontal position.

Sigmentation cavity. - The segmentation cavity is formed at the division of the egg into eight cells, and enlarges progressively up to the time of beginning invagination (Figs. ${ }^{6} 6-$ 48). The roof of the segmentation cavity is shown by median sections to consist of a single layer of cells, while the floor is composed of a mass of large yolk-cells with ill-defined boundaries. The cells of the roof are somewhat columnar and, up to the time when invagination begins, divide for the most part vertically. Scott and Osborn ('79) state that in Triton teniatus the roof of the segmentation cavity is only one cell thick, in which respect it agrees with that of the egg of Petromyzon and differs from that of Rana. v. Bambeke (80) and Hertwig ('82) have not been able to confirm this statement. They maintain that there is no essential divergence in this respect between the frog and the newt. However this may be with regard to the particular species considered by them, I am confident that in Diemyctylus the roof of the seg-. mentation cavity up to a comparatively late period is only one cell thick. In other words, the horizontal division of the roof cells does not occur so early in the newt as it docs in the frog. This is clearly seen if we compare Fig. 48, Plate XVIII with Götte's figures of Bombinator (Entwickelungsgeschichte, Figs. 28 and 29, Pl. II), or with other figures of Anuran eggs at this. 
stage. The section through the egg of Triton teniatus, depicted by Hertwig (Fig. I, Pl. XIII) does not at all correspond with what I find in median sections through the eggs of Diemyctylus at this period.

External appearances. - Beyond a slight increase in the diameter of the egg, due, doubtless, to the formation of the segmentation cavity, there is for some time no visible external change except decrease in size of the cells consequent upon their multiplication. The first signs of gastrulation appear about fifty-four hours after the egg is laid, the temperature of the water being about $18^{\circ} \mathrm{C}$. There is first a slight depression of some of the cells in the middle of the lower pole; this becomes more and more pronounced, and finally results in an irregular pit, such as shown in Fig. 34. This pit grows deeper and its edges become more sharply outlined till there is a deep, nearly oblong depression extending in the direction A-B, Fig. 34. This depression is now at right angles to the future axis of the embryo. Almost as soon, however, as the depression assumes this form, faint sunken lines may be seen running off from the ends of the depression at an obtuse angle. The point of junction of these lines of sinking with the original area of depression is at first perfectly clear, and the angle is well marked, but very soon the angle is obliterated and the depression takes on the rounded semi-lunar appearance which has become familiar by repeated portrayal (Fig. 35). The horns of this half-moon gradually approximate, and in about twenty-four hours after the appearance of the depression the circle of the blastopore is complete (Fig. 36).

The more intimate phenomena of the formation of the blastopore must now be considered.

Invagination. - The view that the archenteron of the amphibia is formed by the infolding or ingrowth of cells that originally were external has been the one very generally upheld by the students of amphibian development. This conventional opinion has, however, been opposed by Moquin-Tandon ('76) and by Houssay ('90), and has recently been attacked with spirit by Robinson and Assheton ('91). These dissenters from the invagination hypothesis believe in its stead, "that the archen- 
teron is formed in situ by splitting amongst the yolk-cells, and that it is entirely surrounded by modified yolk cells." (R. and A.) The entoblast on the latter interpretation takes its origin wholly from the so-called yolk-cells; on the invagination hypothesis it comes in part from infolding of the cells once covering the exterior and is continuous with them at the lips of the blastopore.

It is evident at the outset that the question of invagination or no-invagination can not readily be determined from the inspection of sections. The most that can be derived from sections will be only circumstantial evidence of greater or less significance. In the opinion of some investigators there is to be found in sections certain positive evidence that favors the invagination hypothesis; their opponents deny the validity of such evidence and regard the appearances observed as accounted for more easily on the splitting hypothesis.

If we examine some of the evidence that has been supposed to indicate invagination it cannot be said to carry conviction. Some stress has been laid upon the fact that the cells lining the dorsal wall of the archenteron, and lying opposite to the cells of the yolk-plug, are smaller than those of the ventral wall, and that by this character they show their affinity to the ectoblast cells, with which, moreover, they are in direct connection. It has been shown by Robinson and Assheton, however, that in Rana this difference in cell size does not appear in the early stages of the blastopore, but becomes manifest only after the blastopore is well established. At first there is practical equality in the size of the cells around the blastopore and only later can a difference in size be detected. This is also the case in Diemyctylus. Later on, however, there is a striking inequality of size (Fig. 52). The advocates of the splitting hypothesis (v. Houssay, 90, p. 165) attribute this inequality to the greater activity of the cells forming the dorsal wall of the archenteron. That is to say, the dorsal archenteric cells divide more rapidly than the cells below them, and hence their number is greater and their average size less ; this differentiation is supposed to have taken place in situ. It is obvious that this is a plausible or at any rate 
possible explanation of the difference in cell size; the fact that the dorsal archenteric cells are smaller than the ventral, and resemble in this respect the ectoblast cells, is no proof of their direct genetic connection with the latter: for aught that is known to the contrary a secondary resemblance may have been acquired in situ.

The presence of pigment in the borders of the cells supposed to be invaginated has likewise been taken as proving their external origin, but this cannot be regarded as a more conclusive argument than that drawn from the size of the cells. The pigment, even in early segmentation, is not confined to the cells of the upper pole, but darkens to a greater or less extent the borders of all the cells. At the time the archenteron begins to be formed pigment is found in the cells on both sides of the archenteric cleft, and as the cleft widens and deepens the black borders of the lining cells become more and more pronounced. Furthermore, as is well known, a double line of pigmented cells extends forward beyond the limit of the actual cleft, and this occurs at a stage when it is exceedingly unlikely, if not impossible, that epiblast cells should have invaginated to that distance. The fact that the pigment in this region is found in the opposed borders of two rows of cells cannot be regarded as strengthening the opinion that the presence of pigment signifies invaginated ectoblast cells. The presence of pigment in certain cells, therefore, should by no means lead us to refer those cells to an ectoblastic origin. It might on the contrary be quite as reasonably supposed that the pigment marks physiological activity, and that the less heavily pigmented cells of the ventral wall of the archenteron owe their relative lack of pigment to the more sluggish metabolism attendant upon less rapid cell division. That is to say, the presence of pigment may be directly correlated with the small size of the cells containing it.

The size of the yolk granules has sometimes been taken as affording a criterion of invagination. The yolk granules in the dorsal archenteric cells are much smaller than those in the ventral, and this characteristic is thought to relate the dorsal cells to the ectoblast cells and distinguish them from the cells 
of the yolk-plug. This distinction, however, does not exist in early stages of the archenteron, as has been well shown by Houssay for the axolotl. I have observed a similar condition in Diemyctylus: at the beginning of the formation of the archenteron the yolk granules in the surrounding cells are practically identical in size, and it is only in later stages that the yolk granules are smaller in the dorsal cells. ${ }^{1}$ This reduction in the size of the yolk granules may perhaps depend, like the size of the cells and the presence of pigment, upon the activity of the cells themselves and may have been due to the differentiation of cells in situ. The size of the particles of yolk is consequently not a sound criterion of the source of the cells.

No one, of these characteristics of the cells of the dorsal wall, therefore, can be regarded as in any way satisfactory evidence for infolding: neither the size of the cells nor that of the yolk granules, and assuredly not the accumulation of pigment. All of these appearances may be explained perhaps equally well by supposing a differentiation of the cells iu situ. Houssay regards the difference between the dorsal and ventral walls as due simply to a difference in rapidity of development, and believes that the ventral cells pass through the same stages as the dorsal, but more slowly. Why there should be this striking disparity he does not attempt to explain.

The evidence thus far adduced for invagination is, to say the least, inconclusive. Let us next examine that brought forward

1 Houssay, taking his cue from Nuel ('8I), believes in the subsequent regeneration of these reduced yolk granules! "Il y a plus. Ces cellules de la paroi dorsale, qui avaient d'abord une apparence identiques aux cellules vitellines, puis qui ont acquis une forme voisine de celle das éléments épiblastiques, vont de nouveau perdre cet aspect, acquérir de nouveau une grande taille et de gros granules, en passant de l'état d'activité qui préside à la formation de l'intestin, a l'état de repos où elles demeurent tant que dure la formation du système nerveux" (p. r7o). Houssay seems to ignore the grave physiological difficulties that lie in the way of accepting such an independent existence for yolk granules; and it is certainly difficult to appreciate the precise advantage to the embryo of removing nutritive material from one portion of the developing egg to deposit it in the form of large yolk granules in the cells of the dorsal wall! It is hardly necessary to suggest the fallacy involved in comparing sections of different stages, especially in such a respect as the size of yolk granules, and assuming continuity of development. 
in support of the splitting hypothesis. This evidence is, unfortunately, almost wholly of a negative character, and concerns itself with showing that the appearances observed in sections do not necessarily indicate invagination, but tally equally well - or, as is believed, better - with the hypothesis of delamination. The direct evidence for delamination seems to me singularly inadequate. I confess that it is difficult for me to understand why so much stress should be laid by the advocates of delamination upon the fact of the equality of cells, yolk granules, and pigment at the first origin of the archenteric cleft. While this fact does perhaps leave open the possibility of a subsequent differentiation of these elements in situ, it in no way indicates the probability of such an occurrence. It might be urged by the upholders of invagination, with perfect justice, that, although the first step in the formation of the archenteric cleft may be a split between the yolk-cells, there is no reason why one should not suppose invagination immediately to follow. There is not a shred of evidence to show that the large cells at first surrounding the mouth of the blastopore are not subsequently pushed in by the ingrowth of ectoblast cells. No positive evidence whatever exists to prove either the impossibility of invagination or the likelihood of no-invagination. I find it difficult to gather the reasons that have influenced Houssay, and Robinson and Assheton to adopt the view that invagination does not occur. Even if some of the usual arguments for invagination have no weight and have been carelessly advanced, that fact would hardly prove that the process of invagination did not occur.

I must here advert to the elementary fact that there are really two processes of "invagination" concerning which it is important to distinguish clearly. "Invagination" may mean either that the upper small (ectoblast) cells grow down over the large cells of the yolk-plug, or that the cells around the rim of the blastopore are turned in and rolled under to form the wall of the archenteron. Now either one of these invaginative processes may occur alone, or both may occur together. If I understand Robinson and Assheton correctly they maintain that the small cells neither grow down nor fold in (Rana), 
"For during the formation of the blastopore the epiblast does not grow over the yolk-cells, enclosing them by a process of epibolic invagination" (p. 46I). While I think there is good reason for holding that the process of ectoblast formation is not one of simple overgrowth, but is modified by the advancing differentiation of cells in situ, I do not see any reason for the wholesale denial of such overgrowth. There can be no question that the roof of the segmentation cavity contains much more material in the early stages than in the later (cf. Figs. 46-48). The disappearance of such a mass of substance may be best accounted for by supposing that cell proliferation has carried it further towards the lower pole. In fact, as I shall state presently, there is conclusive evidence that such overgrowth does occur. Robinson and Assheton, furthermore, fail to see that denial of this epibolic invagination involves them in serious difficulties when they attempt to explain the closure of the blastopore.

I have fortunately succeeded in obtaining decisive ocular evidence that the small cells around the lips of the blastopore are actually infolded. With the aid of the underlying plane mirror previously mentioned, I have repeatedly watched in the living egg the slow rolling in of the small epiblast cells. This I have seen in the newt and in Rana palustris, and, through the kindness of Mr. A. C. Eycleshymer, I have repeated his observations upon Amblystoma punctatum, where the large size of the cells renders the demonstration peculiarly convincing. The small cells roll down over the others (epibolic invagination), and at the same time the cells around the edge of the blastopore turn in and disappear from view (embolic invagination?). It is obvious that the appearance of embolic invagination may be in part delusive. The small cells at the rim of the blastopore may simply remain stationary, while the other cells grow down over them. In other words, it may not be wholly cell proliferation that forms the "invaginated hypoblast," but a simple modification of the process of epibole. In the one case, the "invaginated hypoblast" is active, in the other, passive. I do not at present see how it is possible to differentiate sharply the two processes, and distinguish between 
the parts played by each. Epibole and embole certainly run into each other at the lip of the blastopore, and I see no reason for supposing that the process of cell proliferation, which is so active in the exterior cells, ceases when the cells have been engulfed by the epibolic overgrowth. Of the existence of the latter process there can be no question. Two hours spent in watching the marginal blastoporic cells in the living amphibian egg will enable any one to determine this to his complete satisfaction.

\section{Fate of the Blastopore.}

It is with some diffidence that I take up the question of the fate of the blastopore, since for a long time the literature on the amphibian blastopore has been increasing in quantity if not in cogency. It would be a superfluous task to review in extenso the far from concurrent opinions, since an excellent summary of the literature has been quite recently given by Erlanger ('89), and by Robinson and Assheton ('91), to mention only two of the most recent. ${ }^{1}$ On one point only is there practical agreement among all the later investigators, namely that the amphibian anus is either a remnant of the blastopore opening, or a breaking through in that region of the embryo at one time occupied by the blastopore. Whether it is in all cases a persisting portion of the original blastopore, or is in some cases a new opening of the old blastopore raphe, is, however, a much disputed question.

It seems necessary for the sake of clearness, if for no other reason, to distinguish between the Anuran and Urodelan blastopore. There seems good cause to suspect that the phenomena attending the closure of the blastopore differ in the two groups; at any rate, nothing is to be gained by a hostile criticism of the results obtained from the study of one group upon the basis of results obtained from the study of the other.

1 It seems a curious oversight on the part of Robinson and Assheton that they make no mention either of Hertwig's papers (Jenaische Zeitschr f. Naturwiss., I882 and I883), or of Schanz's (Jenaische Zeitschr, I887), since these papers must be regarded as among the most important contributions to the literature of the blastopore (cf. Erlanger, '91). 
The anus in the Anura is apparently, in some forms at least, a new formation in the region of the primitive blastopore. Although my own observations have thus far been exclusively upon the newt, and my belief has consequently the weight only of an obiter dictum, I think the careful observations of Schanz ('87), Erlanger ('91), and Robinson and Assheton ('91), are descrving of acceptance. Even if we admit the possibility that the fate of the blastopore is different in other members of the same group, I see no way of escape from the facts adduced by these authors in the specific instances which they consider. It is possible, nay probable, that variations even among individuals of the same species may account for the discordant results of other investigators. Viewed in the light of Erlanger's suggestion ('89, p. $25 \mathrm{I})$, that the Anuran anus should be regarded as a secondary formation, I see no reason why we should not expect occasional and perhaps frequent reversion to the more primitive condition. I may here suggest that the interesting observations of Ziegler (92) on the living egg of Rana may perhaps be referable to some such explanation. Ziegler's observations, moreover, although highly interesting and important, afford no conclusive proof of the actual persistence of a portion of the blastopore opening. There is nothing in his figures that proves that the depression pictured communicates at all stages with the archenteron. That, I takc it, could be demonstrated only by sections, though it is a supposition which the surface indications render plausible.

In the case of the Urodela there seems to be greater unanimity of opinion. The work of Miss Johnson ('84), Schanz (87) and Morgan (89) have practically established the fact that the Urodelan anus is a remnant of the blastopore which has remained open from the first. I shall show presently that my own observations on Diemyctylas support this view.

This main fact, however, admits of many variations of opinion as to essential details. What portion of the blastopore is it that persists as the anus? What are the relations of the socalled neuropore to the blastopore and to the anus? How is the primitive streak related to the blastopore? What is the method of closure of the blastopore? It is clear that 
the answers to these questions involve large theoretical considerations.

In my description of the closure of the blastopore in the newt, I shall, in this section, confine myself chiefly to a discussion of the questions already advanced and shall defer to a later section all extended reference to the origin and development of the germ-layers.

Method of closure of the blastopore. - There are several conceivable modes by which the blastopore might close. It might close either (I) by a convergence of all the marginal cells towards a central point, or (2) by a sort of peristaltic wave of approximation of the lateral cells from behind forwards or from before backwards, or (3) by a similar growth of the cells dorsally or ventrally, or (4) by a combination of any or all of these processes. Surface views afford most valuable evidence on this point, and for these I have learned to rely chiefly on the study of the living egg, since prolonged study of prescrved specimens has served to convince me of the confusing nature of the evidence derived from comparison of different eggs in different stages.

The process in the living egg, as I have observed it in the newt, is usually as follows. When the circle of the blastopore is completed (Fig. 36) there ensues an approximately uniform convergence of cells from all sides. This convergence at first takes place at a nearly uniform rate, as shown by observation of the cell movement at different parts of the blastopore rim. It continues for a very varying length of time, but seems in all cases to be the first step in the dwindling of the blastopore. This method of closure by centripetal convergence of the marginal cells is substantially the method witnessed in some Annelids (Nereis, Rhynchelmis). In the newt, however, such uniform convergence does not continue to take place up to the end. Before the blastopore is obliterated, and usually while its diameter is still considerable, the cells at the ends of a line drawn through the blastopore parallel with the mid-axis of the embryo lag behind the cells at the sides. These latter press rapidly in towards the middle, and the result is the formation first of an oval (Fig. 38), then of a longitudinal slit (Fig. 40). This movement brings it to pass that the yolk-plug is covered 
first at the ends of the mid-line and remains exposed longest in the middle. (Fig. 38.)

There are, however, important variations in the process above outlined. Such a one is depicted in Fig. 37. Here, it will be observed, the closure has been chiefly from behind forwards as indicated by the faint groove running off posteriorly. Sections through the region of this groove show a fusion of the layers, and I have found by the reconstruction of embryos in this stage that this fusion of layers is of greater extent than the fusion at either the anterior or the lateral lips. This condition is comparable with that described by Robinson and Assheton ('91) in the eggs of Rana temporaria. In the newt the posterior groove seems to be more clearly marked than in Rana and the visible remnant of the yolk-plug is oval rather than circular in outline. I agree with these authors in believing that in eggs showing such a structure there has been a coalescence of the posterior lips of the blastopore, but I cannot regard this as illustrating the "typical" method of closure for the blastopore of the newt. It must, I think, be considered rather as the usual preliminary to a stage similar to that shown in Fig. 38 , though I have unfortunately been unable to determine this point in the living egg. I am certain that in the newt the whole blastopore rarely, if ever, closes by the progressive coalescence of the posterior lips alone, although I admit that such postcrior coalcscence does sometimes anticipate to a greater or less degree the movement of the anterior cells. The simultaneous approximation of the lateral cells both anteriorly and postcriorly, as shown in Fig. 38 , is the more usual occurrence in the newt.

Hertwig ('82, Pl. XII, Figs. 3 and 4 ) has figured stages in the closure of the blastopore of Triton teniatus that agree very closely with what I have obscrved in Diemyctylus. Fig. 4 (Hertwig, '82) shows the lines of closure stretching off both in front of and behind an oval yolk-plug. I infer that this must indicate the same general method of antero-posterior closure which occurs in Diemyctylus. Morgan ('89, P1. XLII, Fig. A) also has figured a similar stage for Amblystoma, but attributes the appearance (p. 356) to the elongation of a circular blasto- 
pore. I am unable to convince myself that in the newt there is anything more than a continuation of the process of shrinkage. ${ }^{1}$

Another not uncommon condition is illustrated in Fig. 39. This is somewhat older than the stage shown in Fig. 38 and is marked by the still circular outline of the very small blastopore. The lines running off behind and in front indicate the seams of closure.

The closure of the blastopore in the newt, then, may be considered to take place in the following manner. There is first a convergence at a uniform rate of cells from all parts of the margin. This process becomes gradually modified, sometimes very early in the blastopore history, sometimes very late, by the more rapid movement of the cells on either side of the axial mid-line. At this point considerable variations arise. (I) The movement of the posterior cells may anticipate that of the anterior, in which case the blastopore "closes from behind forwards." This occurrence I believe to be quite frequent in the newt. About ten per cent. of the preserved eggs that I have examined seem to be closing in this manner. The point of great interest in these cases, and one which my study of the living egg unfortunately leaves unsettled, is whether a closing also "from before backwards" may not immediately succeed the stage figured (Fig. 37). It is worthy of note in this connection that the blastopore in eggs of the stage showing only a posterior groove is usually of about the same size. When the eggs are in the stage in which the blastopore opening is nearly obliterated there are, I think invariably, lines running in both directions (Figs. 38 and 39). (2) There is the possibility that the movement of the anterior cells may anticipate that of the posterior. This, if it happens at all in the newt, is not common. That it occurs occasionally is, I think, probable. Only in this way can I explain certain puzzling cases in which such a line as shown in Fig. 57 is seen running off anteriorly. (3) The movement of the anterior and posterior cells may be approximately synchronous, in which case the blastopore may be

1 Dr. Morgan has since informed me that he did not intend to imply actual elongation, but simply the narrowing to an oval of the earlier circular outline. 
considered as "closing" in both directions. This I think is what usually happens in the newt.

The lateral cells continue to press in towards the mid-line until the blastopore exists only in the form of a longitudinal slit. This at first opens into the archenteron along its whole length, but soon the ingrowing lateral cells meet along the middle of the slit, leaving a small circular orifice at each end. The anterior of these openings is the evanescent neuropore; the posterior remains open as the permanent anus (Fig. 42).

It is evident from the facts above adduced that very great significance cannot be attached to the manner of closure of the blastopore. The work of other observers points to the same conclusion. The blastopore in amphibia, and in other vertebrates also, has been described as closing both from behind forwards and from before backwards, as well as in both directions simultaneously. The closing of the Urodelan blastopore in the middle has been observed by Schanz ('87) and Morgan ('89), and is a constant occurrence in the newt. Whether this mesial coalescence is in all cases preceded by a coalescence at either end of the blastopore varying in character and extent, or whether the mesial coalescence sometimes steps in directly upon the cessation of the uniform convergence of the marginal cells seems to me an open question. I am convinced that in the newt, at least, occasional variations cover several of the possibilities of antero-posterior coalescence. The mesial approximation of the lateral lips, resulting first in the formation of a longitudinal slit and then of an anterior neuropore and a posterior anus seems invariably to follow the diversity of the earlier conditions.

Variation in the manner of blastopore closure in the same group of animals, or even in the same species, is not uncommon. E. B. Wilson ('89) observed in Lumbricus "a considerable variation in the closure of the blastopore, owing to differences in the rate of folding between the sides and the posterior margin of the blastopore. As a rule, the sides fold in more rapidly than the hinder lip, thus giving rise to a slit-like blastopore, but in some cases the reverse is true, so that the blastopore never appears as a slit, but always as a rounded opening" 
(p. 400). In Lumbricus the blastopore closes from behind forwards, in Rhynchelmis and Clepsine from before backwards.

To what, then, shall we attribute the variations in the closure of the blastopore? Evidently they can be due to no phylogenetic necessity, but rather to slight, unimportant individual differences in the rapidity of cell proliferation and movement at different parts of the blastopore rim, and may perhaps in the final analysis rest upon trivial mechanical causes.

One important fact, however, is brought out into sharp relief by the work of all investigators of the amphibian blastopore, namely, that the blastopore is closed at least in part by closing in of the lateral lips along a median line. I cannot regard it as an objection against the theory of concrescence of the vertebrate embryo that the blastopore does not always close by retrogressive fusion of its lips. On the contrary, I think variations such as we have noticed are distinctly the outcome of secondary and fluctuating conditions. Whether the blastopore closes "from behind forwards" or "from before backwards," or in both directions, does not appear to have great significance, and does not in the least affect the salient fact of coalescence of the lateral lips along a mid-line.

Neuropore and Anus. - It is evident, from what I have already stated, that the relative position of neuropore and anus cannot be constant. I am thoroughly convinced, after a careful examination of many preserved eggs, and after observation of the blastopore closure in the living egg, that the anus may lie in almost any portion of the original mid-line through the blastopore. Fig. 42 shows the greatest separation of neuropore and anus that I have ever observed. The two openings usually lie much closer together, at a distance represented by about one-third of the interval shown in Fig. 42. The examination of preserved specimens inclined me at first to believe that the neuropore was pushed back from some such extreme initial position as that represented in the figure, but study of the living egg showed me that such is probably not the case, and that the gradations I observed were individual variations and not consecutive stages. The neuropore and anus, then, have their position, relative and 
absolute, determined by the extent of antero-posterior coalescence. The longest space that I have observed between the two openings is represented in Fig. $4^{2}$, and it must be noticed that this extreme case affords no support to the view that there is an elongation of a circular blastopore. In such an egg as that shown in Fig. 39 the other extreme is indicated; in this instance the distance separating neuropore and anus would obviously be slight.

The neuropore is quite transitory, remaining open but a few hours, and closing long before the meeting of the medullary folds. The position of the neuropore is more constant than that of the anus; it always lies near the anterior end of the blastopore, and the fused area in front of the neuropore is, in all specimens I have examined, less than the fused arca behind the anus. Fig. 63 represents a horizontal section through Fig. 40, in which the blastopore has narrowed to a longitudinal slit. Fig. 62 shows a sagittal section through a stage similar to that shown in Fig. 42. The neuropore lies dorsally (anteriorly) and the anus below, and between these is shown the mass of ingrowing lateral cells which have just met in the mid-line. Regarding the significance of this strangely persistent ancestral structure, conjecture is at present idle. We are not even, I think, able to determine whether this anterior portion of the blastopore primitively opened freely to the exterior as the neuropore, and has been only secondarily caught in as the "neurenteric canal" by the precocious closing: of the medullary folds, or whether the reverse is true.

The posterior opening remains as the permanent anus. The backward extension of the medullary folds brings the anus to lie just bchind them (Fig. 43). The external appearances do not differ from those pictured by Ziegler ('92) for the frog, while sections show that this opening in the newt maintains its integrity throughout, and eventually functions. as the anus. The sections figured by Miss Johnson ('84) adequately represent in this respect the conditions $I$ have found in the later stages of the newt.

Primitive Streak. - The term primitive streak, originally applied to a certain darkened region in the posterior part of 
the area pellucida of the chick blastoderm, has since come to obtain a wider significance. Homologous areas have been alleged to exist in the early stages of other vertebrates, and some of these cases have been looked upon as throwing light on the meaning of this primitive and persistent structure. The macroscopic appearance of a "streak" is simply the outward expression of an inner thickening of the embryonic area, due to the fusion of the three primary germ-layers. This fusion must be regarded as the most characteristic mark of the primitive streak and can evidently be discovered only from sections, so that observations of a "primitive streak" based on surface views alone are of doubtful value. Taking as a criterion of the primitive streak, then, the fusion of germ-layers, what is the hidden significance of this early union of the three layers in a linear mass or streak, the long axis of which invariably coincides with the long axis of the embryo?

It is a fact of no small importance that the rim of the blastopore is the region where the fusion of layers first makes its appearance in many vertebrate embryos. This fact alone tempts one to believe that the primitive streak is the result of the fusion of the lips of the blastopore in the mid-line. The comparison of the line of fusion of the lips of the Elasmobranch blastopore with the primitive streak of the Amniota was made long ago by Balfour, who, however, expressly disclaimed any implication of homology.

Assuming that in the newt the primitive streak is the linear mass of fused germ-layers formed by the bringing together of the blastopore lips, let us determine its extent and character without, for the instant, any reference to possible homologies. Figs. 52 and 55 . represent median sagittal sections through early blastopore stages. The only region of fusion is that immediately around the yolk-plug. This fused area is seen in these sections to be slightly greater at the posterior (ventral) lip, but this fact does not come out so clearly as in reconstructions. The lateral lips of the blastopore begin to approximate shortly after the stage shown in Fig. 55, and a horizontal section through Fig. 40 in the line $63-\sigma_{3}$ (Fig. $6_{3}$ ) shows the lips almost touching. A median sagittal section through the next 
stage (Fig. 42) affords us a good view of the primitive streak at its period of maximum extension (Fig. 62, x, z). The lateral lips have just met in the mid-line, and the fused area (Figs. 42 and 62) reaches from a point in front of the neuropore $(x)$ to a point some distance behind the anus (z), the only breaks in its continuity being the small perforations of neuropore and anus. If we adhere to our determination to designate the whole extent of fused area as primitive streak, then there is obviously a portion of the streak that lies in front of the neuropore and another portion that lies behind the anus. There is, however, an important consideration that tends to qualify the acceptance of such a view. This is the question of the thickness of the fused blastopore rim, - the germ-ring. For it is obvious that a portion of this fused mass will in any event lie in front of the neuropore, and, unless it exceeds in extent the thickness of the original germ-ring at this point, cannot be strictly regarded as formed by fusion of the lateral lips. Now comparison of Fig. 62 with Figs. 52 and 55 shows that this is actually the case, that the fused area in front of the neuropore is no greater than the thickness of the germring, and that therefore the neuropore in this instance probably lies at the anterior end of the blastopore. If we apply the same test to the fused area behind the anus ( $c f$. the lower lip in Fig. 62 with Figs. 52 and 55) we discover that the thickness is considerably greater than the thickness of the original blastopore rim, and we must therefore conclude that the anus cloes not lie at the posterior end of the original blastopore, but at some distance in advance of it. These facts come out still more clearly on comparison of the thickness of the lateral lips (Fig. 63) with that of the anterior and posterior lips (Fig. 62). The primitive streak, then, is that fused mass formed by the median meeting of the lateral lips plus the thickness of the anterior and posterior lips of the germ-ring. ${ }^{1}$

The early fusion of layers, both anteriorly and posteriorly,

\footnotetext{
${ }^{1}$ In making this statement I do not wish to be understood as implying a constant thickness for the germ-ring from the moment of its first inception. On the the contrary I believe that cell proliferation usually modifies the original thickness, although to a comparatively slight extent.
} 
is shown in Figs. 49-5I. Here the primitive groove is deep, and is interrupted in the middle by the still exposed yolk-plug. Fig. 58 is a horizontal section through a stage somewhat older than that shown in Fig. 42, and represents the primitive streak and primitive groove. This condition results, it is evident, from the fusion of the lateral lips depicted in Fig. 63. A still later aspect of the primitive streak is represented in Fig. 65. This is a section through the hind end of an egg slightly younger than that shown in Fig. 44, and shows the somewhat dorsal position of the streak at this time. The neuropore has by this time vanished, and the primitive streak in consequence extends with unbroken continuity in front of the anus. The section figured is the twelfth in front of the anus, and there are ten sections more before the anterior limit of the primitive streak is reached. Fig. 59 is the eightecnth section anterior to Fig. 65, and Fig. 53 is the thirty-seventh anterior to Fig. 59.

The primitive streak and groove as they appear in surface views are shown in Fig. 42 as the dark line betweer the neuropore and anus. Later these surface features cannot be detected; the groove is completely obliterated, but sections reveal to us the presence of a primitive streak running both backwards and forwards from the anus (Fig. 65).

It is this primitive streak in front of the anus which was looked upon by Miss Johnson ('84), so far as I can gather from her figures, as lying in front of the blastopore. The two statements carry quite a different signification, as will be cvident to those who have followed my description. I am unable, however, to account for the great forward extension of the primitive streak represented in some of Miss Johnson's figures. In Diemyctylus the fusion of layers by no means reaches so far forward as "the middle of the embryo." No more can I reconcile my observations with those of O. Schultze ('88) on Rana fusca. Schultze depicts a primitive streak which "von der clorsalen Urmundlippe sich nach dem Kopfe hin allmählich ausdehnt, und wächst also der Primitivstreif auch bei den Amphibien von hinten nach vorn." (p. 330.) However it may be in these animals, in Diemyctylus, I am confident that 
there is no such forward extension of the fused mass of layers.

The length of the primitive streak in Diemyctylus never exceeds or indeed equals the diameter of the original blastopore. This, too, is despite the probable additions to the fused area due to cell proliferation. I attribute the differences in the length of the primitive streak of Dicmyctylus to the variations in the amount of centripetal convergence of the marginal cells. Early meeting of the lateral lips will produce a long primitive streak, late mecting a short one.

Surface views, as I have already stated, do not show in the newt any trace of a true primitive streak in front of the blastopore. There is, however, a wide, shallow groove on the dorsal aspect of the embryo ("Rückenrinne," "sillon médian ") which might perhaps be taken for the primitive groove. There is no fusion of layers in this region (Fig. 54, n.g.), and since I must persist is regarding the fusion of layers as the criterion par excellence of the true primitive streak and groove, I must consider this second groove as at least in some degree an independent structure. I shall designate it accordingly as the neural groove (Figs. 40-42, n.g.). The neural groove at its first appearance is not connected with the primitive groove which lies posterior to it, but is in the early stages separated from it by a ridge of cells (Figs. 40-42). Later on the neural groove extends backward to the primitive groove so as to appear continuous with it. The neural groove appears in sections as a shallow depression of the ectoblast, the layers beneath not being involved (Figs. 53-54). Since the formation of the notochord takes place at about this period it seems possible that the uplifting of the notochord cells may have something to do with the external appearance of a "streak" which is sometimes described. More often only the "groove" is apparent externally.

I may perhaps be allowed to suggest that the depression of the ectoblast may in itself account for the "fusion" described by Schultze ('88). It may possibly have come about that the sinking in of the neural groove (" $p r$." in Schultze's figures 5, $6,7)$ changes the earlier condition of separate layers (Schultze's 
figures $I, 2,3$ ) into a stage of apparent fusion. I put this forward, however, only as a mere suggestion to be tested by future observation of Anuran embryos of this stage. Schultze's figures do not convince me that the "fusion" along the median dorsal line in Rana is in any way the equivalent of the primitive streak in Diemyctylus. (Cf. e.g. Figs. 58 and 65 with Schultze's Figs. 5, 6, 7.)

The neural groove, which is always quite shallow along most of its extent, becomes, soon after its appearance, much deeper in the extreme anterior portion. This deepening is evidently the "pit" mentioned by Miss Johnson ('84, p. 662). There is, as will be seen in Fig. 64, an apparent fusion of layers at the base of this pit. I hesitate, however, to attribute any special significance to this fusion since it is isolated and limited in extent, and since I am convinced that the appearance of fusion is due chiefly to the dipping in of the superficial ectoblast.

The meaning of the neural groove is, I confess, very puzzling. I am inclined to think the groove may be caused by the mechanical stresses that attend the development of the neural folds, but am poorly satisfied with so nebulous an explanation. I am compelled, nevertheless, to accept sone such interpretation rather than any that would relate it to the primitive groove, from which I believe it to differ utterly in origin, structure and significance. It will be seen, then, that I regard the primitive streak of Amphibia as formed by fusion of the blastodermic layers, and that this fusion is given a linear direction by the coming together of the lateral blastopore lips. In this respect I agree with Schwarz ('84), Goette, ${ }^{1}$ and Robinson and Assheton (91). I agree also with these last-named authors that there is no reason for not including the ventral lip of the anus within the primitive streak. The whole germ-ring, the fused rim of the blastopore, is responsible for the formation of the primitive streak, and the latter structure is simply the result of the fusion of the blastopore lips along the axial

1 I have not been so fortunate as to see Goette's paper (Abhandlungen zur Entwickelungsgeschichte der Tiere, V. Heft, Leipzig, 1890) and know it only by abstracts. 
line. Any one portion of this fused area therefore is just as much entitled to be considered primitive streak as any other.

I must dissent, however, from the singular conclusion of Robinson and Assheton that the primitive streak of Bombinator, Triton and Petromyzon is not homologous with the primitive streak of Rana temporaria. I do not think that variations in direction of formation or in the relative position of the anus are sufficient reasons for the rejection of the homology of this fused linear mass of germ layers. As I have endeavored to show, the method of closure of the blastopore and the position of the anus are not constant, even in the same group of animals, and hence cannot be looked upon as dependent on purely primary causes.

I consider, therefore, that the primitive streak, wherever found, is the expression of the fusion of the blastopore lips. (Prostomanaht). That in different groups of animals the primitive streak should vary widely in character and extent is not surprising.

\section{Germ-Layers AND Notochord.}

Since I believe that the prevailing uncertainty regarding the origin and extent of the germ-layers in amphibia can be successfully met only by a comparative study, I shall not attempt at this time any extensive discussion of my results upon the newt. It does not seem to me likely that the events in a single animal, however illuminating in themselves, can be regarded as "characteristic" or "typical" of the whole group. For this reason I shall for the present simply describe the early development of the germ-layers in the newt and shall draw none but the most obvious inferences from my work.

The ectoblast in the newt is derived chiefly from the small cells of the upper pole, although cells split off from the upper end of the yolk-cells are at first constantly added to these. There is always a certain area of yolk-cells - the yolk-plug which, although originally superficial, is ultimately covered in by the downward growth of small ectoblast cells. I have else- 
where (pp. 333, 334) indicated my reasons for $s$ tating that this epibolic invagination occurs.

The roof of the segmentation cavity is for a long time only one cell thick. About the time invagination begins, the nuclei of the roof cells assume an alternate arrangement like that described by Scott and Osborn ('79), and the formation of a double-layered ectoblast proceeds in the way they describe. This doubling is undoubtedly in part due to delamination, and in part also, as Scott and Osborn suggest, to the alternation of wedgeshaped cells which draw in their edges and come to lie one row above the other (Fig. 54). Sometimes the single layer of ectoblast cells persists to quite a late period (Fig. 55). Whatever the significance of this persistent condition of single-layered ectoblast there is no question that it is radically different from the several-layered condition seen in Anuran embryos of this stage. (See e.g. Schultze's figures of Rana fusca, '88.)

The thinning out of the ectoblastic roof of the segmentation cavity and the concomitant thickening near the rim of the blastopore are, I think, genetically related to the corresponding phenomena attending the formation of the germ-ring in Teleosts.

The entoblast in the newt has in a sense a double origin. It comes in part from invagination of the primitive ectoblast cells and in part from the yolk-cells. Along the dorsal wall of the archenteron it is impossible to distinguish the cells derived from one source from those derived from the other. In such an egg as that shown in section in Fig. 55 we can safely assert only that the most anterior entoblastic cells have been differentiated in situ and that the most posterior cells have been invaginated. Between these two extremes there is no cell that we can point to and surely identify as the foremost invaginate cell. The cells derived from the two sources grade so insensibly into each other that the transition point cannot be detected. It does not seem likely that at the early stage shown in Fig. 55 the invaginate cells reach as far forward as the middle of the embryo, but such a belief must obviously be grounded on other considerations than those afforded by sections alone. The ventral and a considerable part of the lateral walls of the archenteron are formed from the yolk-cells (cf. Figs. 55, 56, 
62 , etc.). The entoblast cells which line the archenteron come in later stages to assume a columnar form (Figs. 57, 62).

I have not been able to discover a stage where I could distinguish only two germ-layers. At the time of beginning invagination there is always an indifferent fused mass of cells around the blastopore rim. It is from this indifferent region that the mesoblast is first formed. The line between ectoblast and entoblast at this point must always be an arbitrary one, since individual cells, which at one time lie externally, are a few hours later rolled under the edge and thus converted into entoblast. Whether we shall regard the mesoblast in this region as coming from the inner or outer germ-layer is largely a matter for personal predilection to determine. It is in a sense true that the mesoblast comes from both layers since it unquestionably develops in just that indifferent, indeterminate region where ectoblast is being continually transformed into entoblast by the rolling under of the outer cells. It has on the whole, however, a much more intimate relation with the invaginated cells than with the cells just on the outer edge.

The mesoblast grows forward in this way from the blastopore rim and has, even in very early stages, a greater forward extension dorsally and ventrally than on the sides. Precisely how much of this is due to forward proliferation and how much to differentiation in situ I have not been able to determine. Except for the comparatively limited fused area immediately in front of the blastopore, the mesoblast is deficient along the median dorsal line (Figs. 54, 55, 59). In the immediate neighborhood of the dorsal line and at a somewhat variable distance in front of the region of fusion the mesoblast comes into close and unmistakable relations with the entoblast. The mesoblast exists here in the form of small, scattered cells which can in some cases be sharply distinguished from the entoblast cells, and in other cases run into them by imperceptible gradations. Fig. 59 shows one of these localities where mesoblast and entoblast are differentiating from the same mass of cells. This conversion of yolk-cells into mesoblast appears to take place first in the hinder part of the embryo and progresses anteriorly. 
The process of mesoblast formation in the extreme anterior end of the embryo is of a particularly interesting nature; the way in which it here develops is represented in Fig. 64. Here the archenteron is in free communication with diverticula of mesoblast on either side. The mesentoblast in this locality is in a similar condition in all eggs of this stage that I have examined although it rarely presents such a strikingly pouched arrangement as is shown in the section I have figured. I have purposely illustrated the clearest case of mesoblastic diverticula that has come under my notice, but the same general arrangement of cells, although often masked and obscure, exists always in this region and almost always suggests diverticula from the archenteron. That such a connection of mesoblast and entoblast indicates an origin for the mesoblast of the newt similar to that typified by the serial gut-pouches of Amphioxus seems to me probable. Such a condition of the mesoblast as exists in the newt tends unmistakably to support Hertwig's well-known coelom theory. Fig. 59 shows a similar state of mesentoblast in the hinder part of the embryo although here the pouches are less pronounced. I have not been able to discover any very clear serial arrangement of these archenteric diverticula, but hesitate to say that such metameric arrangement does not exist. If present at all in the newt, however, it is decidedly obscure. The mesoblast, then, appears first around the margin of the blastopore and is consequently in this region in close connection with the entoblast. This connection of mesoblast and entoblast is ruptured somewhat irregularly and is usually broken first near the middle of the embryo. Precisely as in the case of the entoblast I have not found it possible to distinguish between the mesoblast derived from invagination and that derived from the yolk-cells. This connection of mesoblast and entoblast is confined to a limited area on either side of the dorsal median line ; laterally the two layers are not in contact. The mesoblast appears to originate chiefly, if not solely, in this locality (Figs. $59,60)$, and to proliferate ventrally. In later stages it completely encircles the yolk in the hinder part of the embryo (Fig. 56), but more anteriorly (Fig. 57) the sheets of mesoblast are still separate and do not yet meet in the median ventral 
line. This condition is probably due to the fact that the anterior mesoblast develops more tardily than the posterior, and is therefore really at an earlier stage in Fig. 57 than in Fig. 56.

The mesoblast in the newt has in this sense, then, a double origin. It arises like the entoblast in part from the blastopore rim, and in part from the yolk-cells along either side of the median dorsal line. Like the entoblast, too, the mesoblast from these two sources is separated by no well-marked line, but to all appearances is completely continuous. It 1s, from the outset, however, separated by the chorda-entoblast along the median dorsal line into two lateral sheets, and consequently may be said to have along the greater part of its course a paired origin.

The origin of both entoblast and mesoblast, therefore, points to a fundamental unity of origin for both layers, and indicates that the distinction of mesoblast as "gastral " or "peristomal," although justified perhaps by considerations of convenience, is not grounded on an essential difference. Instead of regarding the mesoblast as having in reality a "double origin," I think we may suppose that the splitting off from the entoblast of the lateral mesoblastic leaves is simply a continuation into the embryo, as it were, of the process of invagination. It is possible that the two modes of mesoblast formation were originally alike and that differentiation has stepped in only secondarily. The continuity of entoblast and mesoblast is certainly a point in favor of this view, as is also the progressive formation of mesoblast from behind forwards. It is also significant that the mesoblastic diverticula are, as in Amphioxus, most pronounced in the anterior part of the embryo (Fig. 64).

Notochord. - The notochord in the newt is, along most of its length, exclusively entoblastic. The early stages of the notochord near the middle of the embryo are shown in Figs. 53, 54. The cells of the median dorsal wall of the archenteron assume a somewhat columnar form, and are gradually pushed up and pinched off until they are completely separated from the entoblast and come to lie above it in the mid-line. The gap left in the wall of the archenteron is soon closed up by entoblast cells, and all trace of the line of origin of the notochord is thus obliterated. The size of the notochordal cells 
soon diminishes, whether by division or by actual loss of substance I do not know; but the effect is to produce cells of about the same dimensions as the mesoblast cells that lie on either side and often come into contact with the notochordal cells (Figs. 56, 57). In many cases, and particularly in the more anterior and posterior portions of the embryo, the notochord begins to be formed while the connection of entoblast and mesoblast still persists in the immediate neighborhood. It thus comes about that both notochord and mesoblast take their origin simultaneously from the same mass of entoblastic cells, and the boundaries of the different elements are consequently hard to define (Figs. 59, 64). The notochord, like the mesoblast, becomes separated from the entoblast in the middle of the embryo while the connection is still intact in the more posterior portion (Figs. 60, 61). The small size of the mesoblastic cells, as compared with the notochordal cells in this region (Figs. 60, 6I), renders impossible any confusion as to the origin of the notochord at this point.

The notochord is formed along its posterior portion to an unknown and probably varying extent by "invaginate entoblast," and in its more anterior portion by "yolk-entoblast." Posteriorly the chord runs into the fused mass of cells known as the primitive streak, and anteriorly into a body of cells poorly defined, but probably entoblastic (Fig. 64).

Since Schultze's ('88) observations were made upon Rana fusca and not upon a Urodelan amphibian, I do not feel called upon to criticise his results. I can merely remark that the large number of cells in the dorsal mid-line of Rana is quite different from the condition existing in the newt. It is possible that this large number of cells may tend to obscure somewhat the reai course of events. I must also point out the fact that certain of Schultze's figures (as Fig. I2a) do not forbid the assumption that in Rana, as in Diemyctylus, the entoblast plays an important part in the formation of the notochord. The fact that both notochord and mesoblast form simultaneously from the same region of entoblastic cells has also doubtless its share in producing delusive appearances.

August, I892. 


\section{LIST OF PAPERS REFERRED TO.}

'64a BALBIANI. Sur la constitution du germe dans l'œuf animal avant la fécondation. Compt. Rend., lviii, pp. 584-588.

'64b BaLbiani. Sur la constitution du germe dans l'œuf animal avant la fécondation. Comparaison de ce dernier avec l'ovule végétal. Deuxième Memoire. Compt. Rend., lviii, pp. 621-625.

'73 Balbiant. Sur la cellule embryogène de l'œuf des poissons osseux. Compt. Rend., lxxvii, p. 1373-1377.

'83 BaLbiani. Sur l'origine des cellules du follicule et du noyau vitellin de l'œuf chez les Geophiles. Zool. Anz., Nos. 155, I56, vi. Dec. 1883 .

'70 v. BAMBEKE, CH. Sur les trous vitellins que présentent les œufs fécondés des Amphibiens. Bull. de l'Acad. roy. Tom. 30, p. 58.

'80 v. BAMBEKE, Ch. Nouvelles Recherches sur l'Embryologie des Batraciens. Arch. de Biol., i, p. 305.

'89 BAteson, W. Journal of Marine Biol. Assn. (Plymouth). N.S.I.

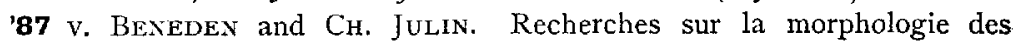
Tunicien. Arch. de Biol., vi, p. 237.

'50 Carus, J. Victor. Ueber die Entwicklung des Spinneneies. Zeitschr. f. zeiss. Zool. 2. Bd., p. 97.

'91 Clapp, Cornelia M. Some Points in the Development of the ToadFish. Journ. Morph., v, p. 494.

'48 Cramer, Herm. Bemerkungen über das Zellenleben in der Entwicklung des Froscheies. Müller's Arch. f. Anat. u. Physiol, p. 20. 1848 .

'89 v. ErLANgrer. Ueber den Blastoporus der anuren Amphibien, sein Schicksal und seine Beziehungen zum bleibenden After. Zool. Jahrb., iv, p. 239 .

'91 v. ERLANGer, R. Zur Blastoporusfrage bei den anuren Amphibien. Anat. Anz., vi, p. 684. Dec. 3 I, I 89 I.

'91 FIscher, G. Beiträge zur Kenntniss des Geotriton fuscus. Verhandl. physik.-med. Gesell. Wiirzb. 25. Bd.

'82 Flemming, W. Zellsubstanz, Kern und Zelltheilung. Leipzig. I882.

'91 GAGE, S. H. Life-History of the Vermilion-Spotted Newt. Amer. Naturalist, p. I084. Dec. 1891 .

'61 Gegenbaur, C. Ueber den Bau und die Entwicklung der Wirbelthiereier mit partieller Dottertheilung. Müller's Arch., pp. 491-526. (Plate xi.)

'75 Goette, A. Entwickelungsgeschichte der Unke.

'90 Heidexhain, M. Beiträge zur Kenntniss der Topographie und Histologie der Kloake und ihrer drüsigen Adnexa bei den einheimischen Tritonen. Arch.f. mikr. Anat., xxv, p. I73.

'77 HerTwIG, O. Beiträge zur Kenntniss der Bildung, Befruchtung und Theilung des thierischen Eies. Morph. Jahrb., iii, pp. 32-53. 
'82 Hertwig, O. Die Entwicklung des mittleren Keimblattes der Wirbelthiere. Jena. Zeitschr. f. Naturzwiss. N. F., vii, p. 286.

'86 HofmMAN, C. K. Zur Entwicklungsgeschichte der Urogenitalorgane bei den Anamnia. Zeitschr.f. wiss. Zool. 44. Bd., p. 570.

'90 Houssay, F. Études d'Embryologie sur les Vertébrés. Arch. de Zoöt. expt., p. I 45.1890.

'77 Iherixg, H. v. Zur Kenntniss der Eibildung bei den Muschein. Zeitschr.f. zeriss. Zool., xxix, p. 6.

'82 I wakawa, T. The Genesis of the Egg in Triton. Quart. Joum. Micr. Sci, xxii, p. 260 .

'84 Jornson, Alice. On the Fate of the Blastopore and the Presence of a Primitive Streak in the Newt (Triton cristatus). Quart. Joum. Micr. Sci., xxiv, p. 659 .

'91 Jordan, EDWin O. The Spermatophores of Diemyctylus. Journ. Morph., v, p. 263.

'89 Korschelt, E. Beiträge zur Morphologie und I'hysiologie des Zellkernes. Zool. Jahrb., iv.

'82 KupfFer. Die Betheiligung des Dotters am Befruchtungsakte. Sitz.Ber. math.phys. Kl. d. k. b. Akad. München. 4. Heft.

'88 LeydiG, F. Beiträge zur Kenntniss des thierischen Eies im unbcfruchteten Zustande. Zool. Jahrb., iii.

'61 Lubbock, J. Notes on the Generative Organs, and on the Formation of the Egg in the Annulosa. Phil. Trans., pp. 595-627; P1. xvi, Fig. 27.

'91 Macallum, A. B. Contribution to the Morphology and Physiology of the Cell Trans. Canad. Inst., i; Pt. 2.

'76 Moquin-Tandon, G. Recherches sur les Premières Phases du Dévcloppement des Batraciens Anoures. Ann. Sci. Nat.Zoöl. Série 6, tom. iii.

'89 Morgan, T. H. On the Amphibian Blastopore. Stud. Biol. Lab́. Johns Hopk. Univ., iv, p. 355.

'90 Morgan, T. H. The Origin of the Test Cells of Ascidians. Journ. Morph, iv.

'81 Nuel, J. P. Quelques Phases du Développement du Petromyzon Planeri. Arch de Biol, ii, p. 403.

'83 Ogata. Die Veränderungen der Pancreaszellen bei der Secretion. Arch.f. Anat. u. Physiol. Physiol. Abth. 1883.

'92 Oppel, A. Die Befruchtung des Reptilieneies. Arch.f. mikr. Anat., xxxix, 215.

'83 Rauber, A. Neue Grundlegungen zur Kenntniss der Zelle. Morph. Jahrb., viii. I 883 .

'77 Reichenbach. Die Embryonalanlage und die erste Entwicklung des Flusskrebses. Zeitschr. f. wiss. Zool., xxix, p. 128. (Pl. x, Fig. 2.)

' 91 Robinson, Arthur, and Assheton, Richard. The Formation and Fate of the Primitive Streak, with Observations on the Archenteron 
and Germinal Layers of Rana temporaria. Quart. Journ. Micr. Sci., xxxii, p. 45 I.

'87 Roux, WilHelm. Beiträge zur Entwicklungsmechanik des Embryo. Arch, f. mikr. Anat., xxix, p. I57.

'91 Rückert, J. Zur Befruchtung des Selachiereies. Anat. Anz., vi.

'92a RücKERT, J. Zur Entwicklungsgeschichte des Ovarialeies bei Selachieren. Anat. Anz., vii, p. I07.

'92b RÜCKERT, J. Ueber physiologische Polyspermie bei meroblastischen Wirbelthiereiern. Anat. Anz., vii, p. 320 .

'83 Sabatier. Noyau Vitellin des Araneides. Compt. Rend., xcvii, p. I 57 O. DeC.

'87 Schanz, Fritz. Das Schicksal des Blastoporus bei den Amphibien. Jena. Zeitschr., xiv, p. 4r r.

'87 Schultze, O. Untersuchungen über die Reifung und Befruchtung des Amphibieneies. I. Zeitschr.f. wiss. Zool. Bd. xlv, p. 77.

'88 Schultze, O. Die Entwicklung der Keimblätter und der Chorda dorsalis von Rana fusca. Zeitschr.f. wiss. Zool., xlvii, p. 325.

'82 Sснётz, J. Ueber den Dotterkern, dessen Entstehung, Structur, Vorkommen und Bedeutung. Inaug. Dissert. Bonn.

'89 SCHWARz, D. Untersuchungen des Schwanzendes bei den Embryonen der Wirbelthiere. Zeitschr. f. woiss. Zool., xlviii, p. Igr.

'79 Scott, W. B., and Osborn, H. F. On some Points in the Early Development of the Common Newt. Quart. Journ. Micr. Sci., p. 449 .

'91 Stieda, Alfred. Ueber die Kloake und das Receptaculum seminis der weiblichen Tritonen. Inaug.-Dissert. Königsb. July, I89I.

'86 Stuhlmann, Fraxz. Die Befruchtung des Anthropodeneies. Ber. d. naturf. Gesell. Freiburg. Bd. i, Heft 5-I2.

'92 Watasé, S. The Phenomena of Sex-Differentiation. Journ. Morph., vi, p. $48 \mathrm{I}$.

'84 WiLt, LuDwig. Ueber die Entstehung des Dotters und der Epithelzellen bei den Amphibien und Insecten. Zool. Anz, vii; No. I67, p. 272. No. 168 , p. 288.

'89 Wilson, E. B. The Embryology of the Earth-Worm. Journ. Morph., iii, p. 387 .

'92 Wilson, E. B. The Cell-Lineage of Nereis. Journ. Morph., vi, p. $36 \mathrm{I}$.

'45 v. Witricir. Observationes quadam de aranearum ex ovo evolutione. Diss. inaug. Halis Sax.

'49 v. Witricit. Die Entstehung des Arachnideneies im Eierstock. Miiller's Arch., p. II 3 .

'91 ZeLLER, E. Ueber Triton viridescens. Jahreshefted.Vereinsf. vaterl. Naturkunde in Württ., p. 170.

'92 ZIEGLER, F. Zur Kenntniss der Oberflächenbilder der Rana-Embryonen. Anat. Anz., vii, p. 2 II. 
REFERENCE LETTERS.

a. Anus,

chr. Chromosomes.

cl. $s p$. "Clear spot."

$d k$. Yolk-nucleus.

ec. Ectoblast.

en. Entoblast.

f. Female pronucleus.

g.v. Germinal vesicle.

m. Mesoblast.

mes. Mesenteron.

n. Nucleoli. nd. Notochord.

n.f. Neural folds.

n. g. Neural groove.

np. Neuropore.

prg. Primitive groove.

prs. Primitive streak.

$s p$. Spermatozoon.

$y$. Yolk.

$y$.p. Yolk-plug-

$y$. sph. Yolk spherules. 
PLATE XIV.

[Figs, I-3 were drawn from nature by Mr. R. Takano.]

FIG. I. Egg just after deposition; accidental break in membrane $\left(\times_{7}\right)$.

FIG. 2. Spermatophore just after discharge; gelatinous base with projecting spine which bears tuft of spermatozoa $(X 2)$.

FIG. 3. Portion of upper pole of egg at time of deposition, showing "clear spot" $\left(X_{48}\right)[c f$. Fig. $2 \mathrm{I}]$.

FIG. 4. Section through young egg; follicle just forming $(\times 500)$.

FIG. 5. Portion of section showing beginning yolk-formation ( $x_{1000}$ ).

FIG. 6. Surface view of portion of the upper pole of living egg soon after deposition ; sp., spermatozoon entering egg in close proximity to the "clear spot," cl. $s p .(\times 20)$.

FIG. 7. Section through young egg showing yolk formation; vacuolation of cytoplasm in upper half of section $(\times 90)$.

FIG. 8. Egg membranes - Nectarus ( $\times 500)$.

Fig. 9. Egg membranes - Dicmyctylus $(\times 500)$.

FIGS. Io-I3. Sections through yolk-nuclei of different stages, $d k$. $(\times 375)$.

FIG. I4. Section showing germinal vesicle in young egg; egg, $31 \mathrm{~mm}$. in diameter ( $X$ I000).

[The outlines of Figs. 4-I 4 were drawn with the Zeiss camera.] 

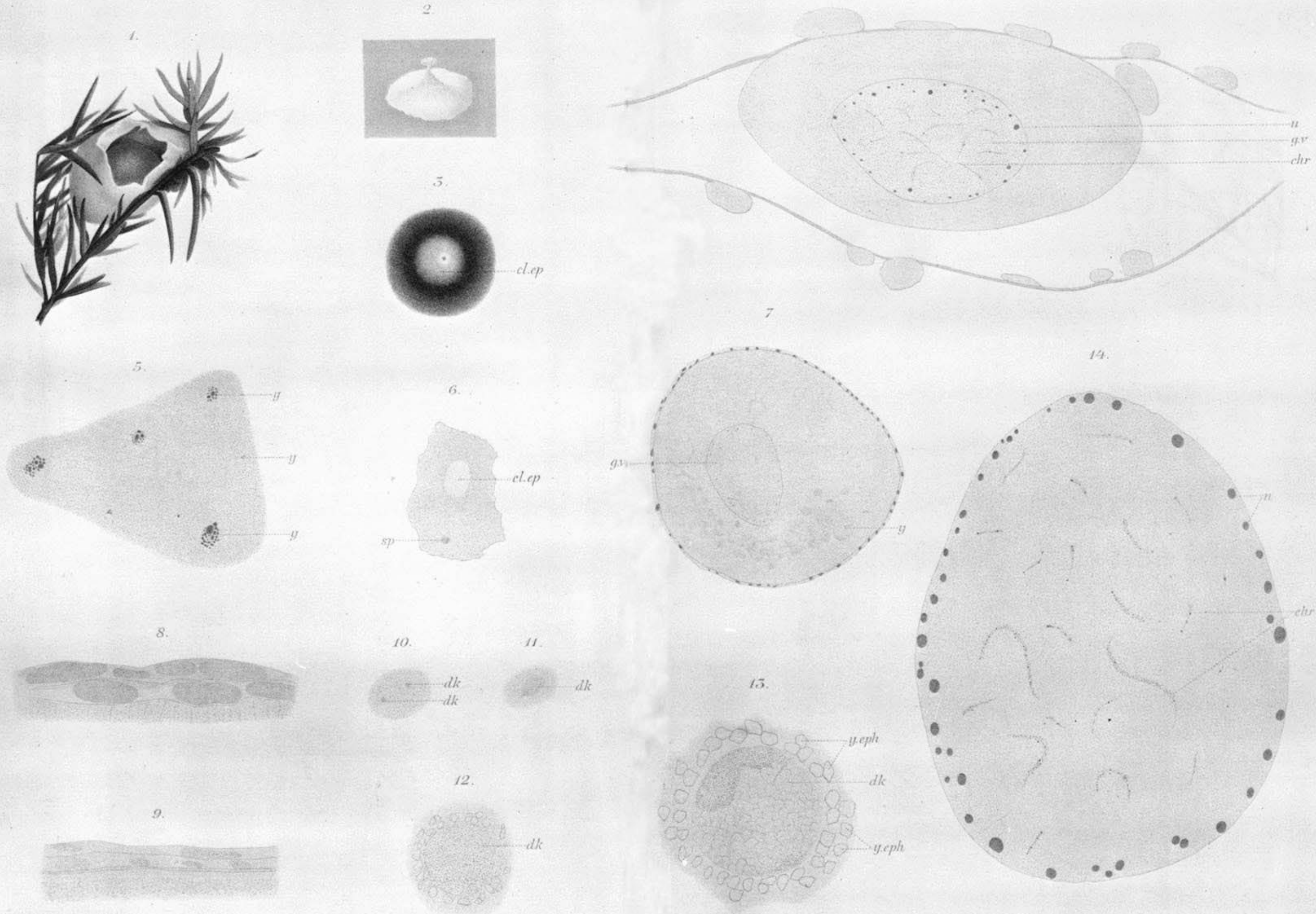
PLATE XV.

FIG. I 5. Section of germinal vesicle; nucleoli migrating to the center and disintegrating $(\times 500)$.

FIG. I6. Section of germinal vesicle $(g . v$.$) ; yolk-nucleus (d k$.) in contact with it; peripheral nucleoli disintegrating. In the yolk-nucleus are three coarsely granular areas which stain more deeply than the rest of the Dotterkern $(\times 375)$.

FIG. I7. Section of germinal vesicle of Rana palustris ( $\times 225$ ).

FIG. I8. Maturation spindle from egg found in body-cavity. Stained with acid fuchsine. $\left(X_{140}\right)$.

FIG. 19. Maturation spindle from egg found in oviduct ( $\times$ I 40 ).

FIG. 20. "Second polar body"; one and one-half hour after the egg was laid; several spermatozoa in the egg ( $\times{ }_{14}$ o).

FIG. 2I. Maturation spindle from egg found in body-cavity. Unstained preparation (X 140).

Fig. 22. Maturation spindle from an egg found in the upper part of the oviduct; the egg possessed a very thin enveloping membrane ( $X_{I_{4}}$ ).

FIG. 23A. Union of male and female pronuclei in egg eight hours after laying. $m$., male pronucleus (?) ; $f$., female pronucleus (?) ( $\times 375)$.

Fig. ${ }_{3} \mathrm{~B}$. Section showing spermatozoon entering egg; two hours after laying. A spindle in the same stage as that in Fig. 20 is present in the egg ( $\left.\mathrm{X}_{\mathrm{I}} \mathrm{O}\right)$.

FIG. 23C. Spermatozoon entering egg; two hours after laying. A spindle of the stage shown in Fig. 20 is present ( $X_{\mathrm{I}} 40$ ).

FIG. 23D. Spermatozoon in egg; four hours after laying $\left(X_{140}\right)$.

[The outlines of all these figures were drawn with the camera.] 


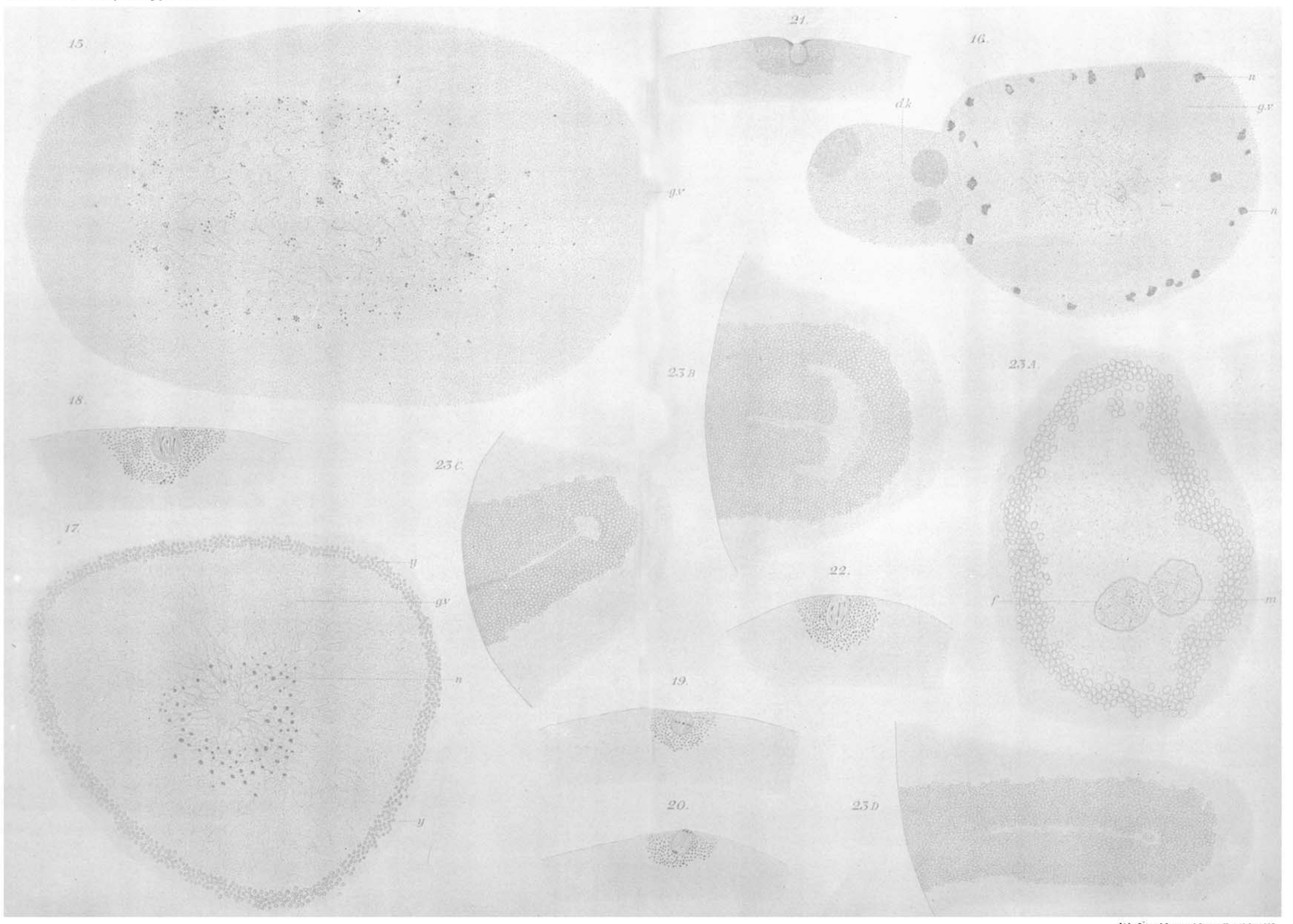




\section{PLATE XVI.}

FiGs. 24-25. Views of upper pole of living egg; first two cleavage planes.

FIGs. 26A-26D. One egg seen from different points of view. 26A, upper pole ; 26D, lower pole.

FIGs. 27 A-27D. One egg from different points of view. 27 A, upper pole; $27 \mathrm{D}$, lower pole.

FIGs. 28A-28D. One egg from different points of view. 28A, upper pole; $28 \mathrm{D}$, lower pole.

Figs. $29 \mathrm{~A}-29 \mathrm{D}$. One egg from different points of view. 29A, upper pole; $29 \mathrm{D}$, lower pole.

Figs. 3oA-3oB. One egg from different points of view. $30 \mathrm{~A}$, upper pole; $30 \mathrm{~B}$, lower pole.

FIgs. 3I A-3I B. Upper (3IA) and lower (3IB) pole views of one egg.

Fics. 32A-32B. Upper (32A) and lower (32B) pole views of one egg.

FIG. 33A. Upper pole of living egg, four hours and three-quarters after the appearance of first cleavage plane; I-I, first plane; 2-2, second.

Fig. 33B. Same egg, ten minutes later than Fig. 33A.

Fig. 33 C. Lower pole of same egg, one hour later than Fig. 33A.

Fig. $33 \mathrm{D}$. Upper pole of same egg, two hours later than Fig. 33A.

Fig. 33 E. Lower pole of same egg, thirty minutes after Fig. $33 \mathrm{D}$.

Fig. 33 F. Upper pole of same egg, fifty minutes after Fig. $33 \mathrm{D}$.

Figs. 26A-32B were drawn with the camera from preserved specimens. All $\times$ zo. The heavy lines indicate the position of the first two cleavage planes.

Figs. $33 \mathrm{~A}-33 \mathrm{~F}$ were drawn freehand from the successive stages of a living egg. The first two cleavage planes are designated by heavy lines, the third set by long dashes, the fourth by short dashes, and the fifth by light full lines. 


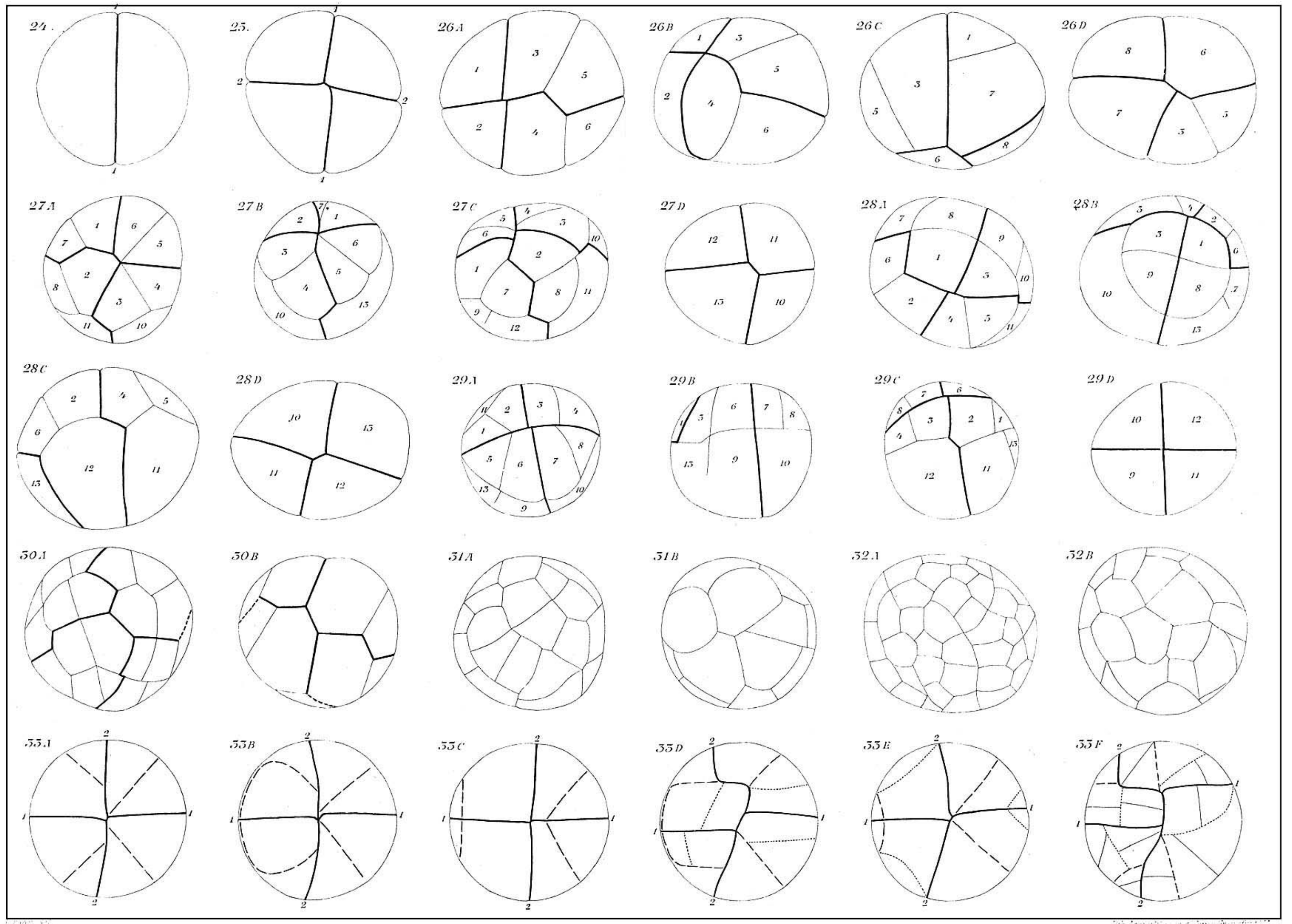




\section{PLATE XVII.}

Frg. 34. Surface view of living egg, showing depression of yolk-cells ( $\times 20)$ -

FIG. 35. Surface view of preserved egg, showing semi-lune blastopore.

FIc. 36. Surface view of preserved egg, showing unusually large circular blastopore, $y p$, yolk-plug.

FIG. 37- Surface view of living egg, showing blastopore closing "from behind forwards."

Fic. $3^{8}$. Surface view of preserved egg, showing blastopore "closing in both directions."

Fic. 39. Surface view of living egg, in somewhat later stage than Fig. 38 .

Frg. 40. Surface view of preserved egg. The blastopore (prg.) - or primitive groove - is now a narrow slit opening into the mesenteron.

FIG. 4I. Top view of same egg as that shown in Fig. 40.

FIG. 42. Surface view of preserved egg. First appearance of neural folds. Neural groove terminates in front of the neuropore, $n p$. The blastopore has closed in the middle, leaving open, however, an anterior neuropore and a posterior anus, $a$.

FIG. 43. Surface view of preserved egg. The anus lies at the posterior limit of the neural folds.

FIG. 44. Dorsal view of preserved egg. Neural folds widely separated.

FIG. 45. Dorsal view of preserved egg, in somewhat later stage than that shown in Fig. 44. The neural folds have approximated, and the neural groove has deepened.

FIGS. 46-48. Vertical median sections through eggs in different stages of cleavage; before invagination has begun $(\times 48)$.

Figs. 49-5I. Horizontal sections through egg shown in Fig. 37, in planes $49-49,50-50,51-51$.

[Outlines drawn with the camera. Figs. 34-45, $\times 20$; Figs. $46-51, \times 48$.] 


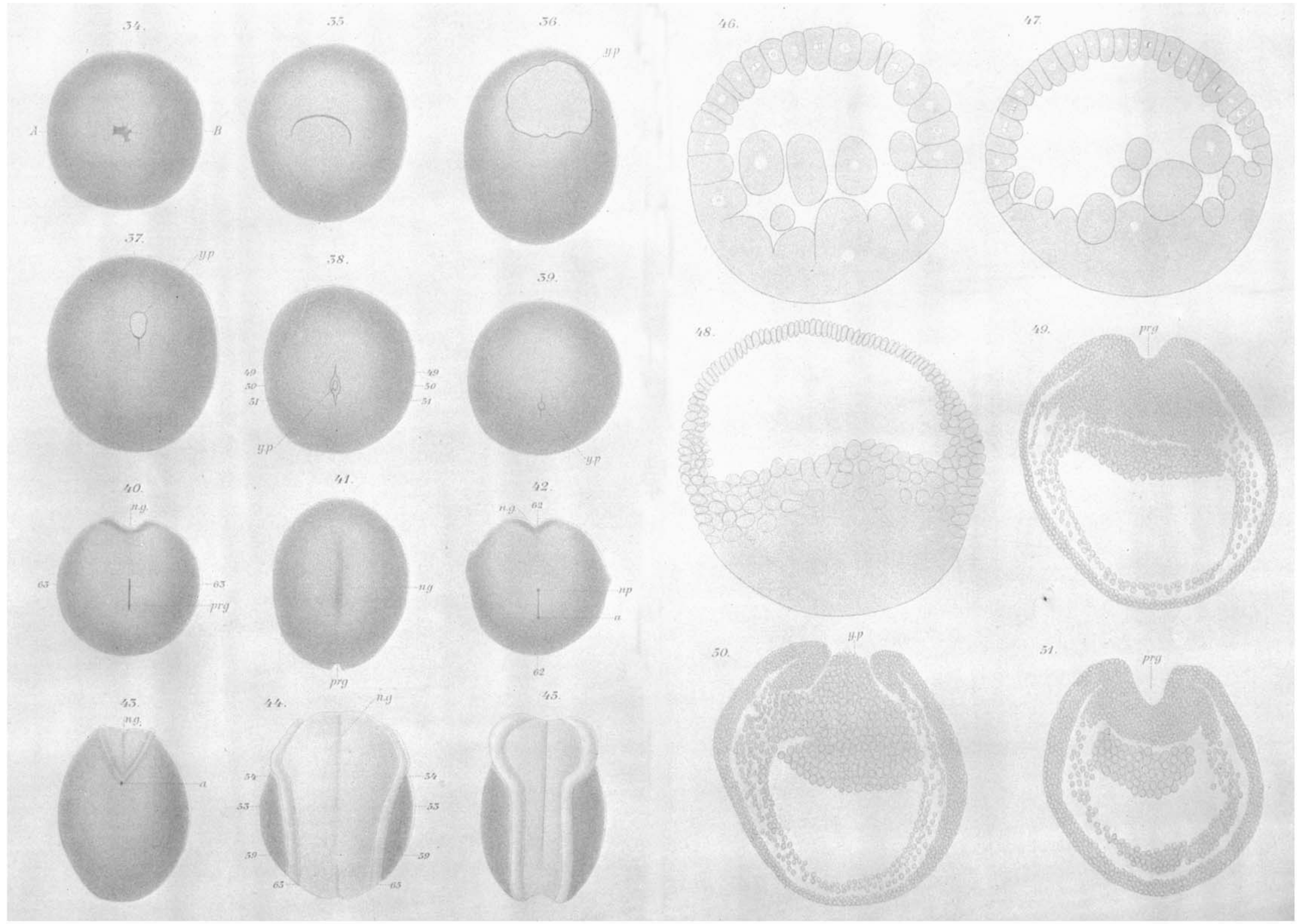




\section{PLATE XVIII.}

FIG. 52. Sagittal section through egg shown in Fig. $36(\times 48)$.

FIG. 53. Transverse section through egg shown in Fig. 44. Thirty-seven sections cephalad to Fig. 59 ( $\times$ 200).

FIG. 54. Transverse section through egg shown in Fig. 44. Thirty sections cephalad to Fig. 53 ( $\times 200$ ).

FIG. 55. Transverse section through an egg with circular blastopore; blastopore, however, much smaller than that shown in Fig. $36\left(\times{ }_{4} 8\right)$.

FIG. 56. Transverse section through egg shown in Fig. 45 ; near posterior end of the embryo $\left(x_{4} 8\right)$.

Fig. 57. Transverse section through egg shown in Fig. 45; thirty-two sections anterior to Fig. $56(\times 48)$.

FIG. 58. Horizontal section through stage between egg shown in Fig. $3^{6}$ and that in Fig. 37. Section is ventral to blastopore $(\times 48)$.

FIG. 59. Transverse section through egg shown in Fig. 44. Eighteen sections cephalad to Fig. $65\left(\times_{4} 8\right)$.

FIG. 60. Transverse section through a stage between egg in Fig. 44 and egg in Fig. 45. Hind end of embryo.

FIg. 6I. Transverse section at about the stage of egg in Fig. 45. Same region as Fig. $60\left(\times_{4} 8\right)$.

FIG. 62. Transverse median section through egg shown in Fig. $4 z(\times 48)$.

Frg. 63. Horizontal section through egg shown in Fig. $40(\times 48)$.

FIG. 64. Transverse section through egg of same stage as that depicted in Fig. 44. Extreme anterior end. Position of cells forming "pouches" were located with the camera $\left(x_{4} 8\right)$.

FIG. 65. Transverse section through egg shown in Fig. 44. Find end $\left(X_{4} 8\right)$. [The outlines of all the figures were drawn with the camera.] 


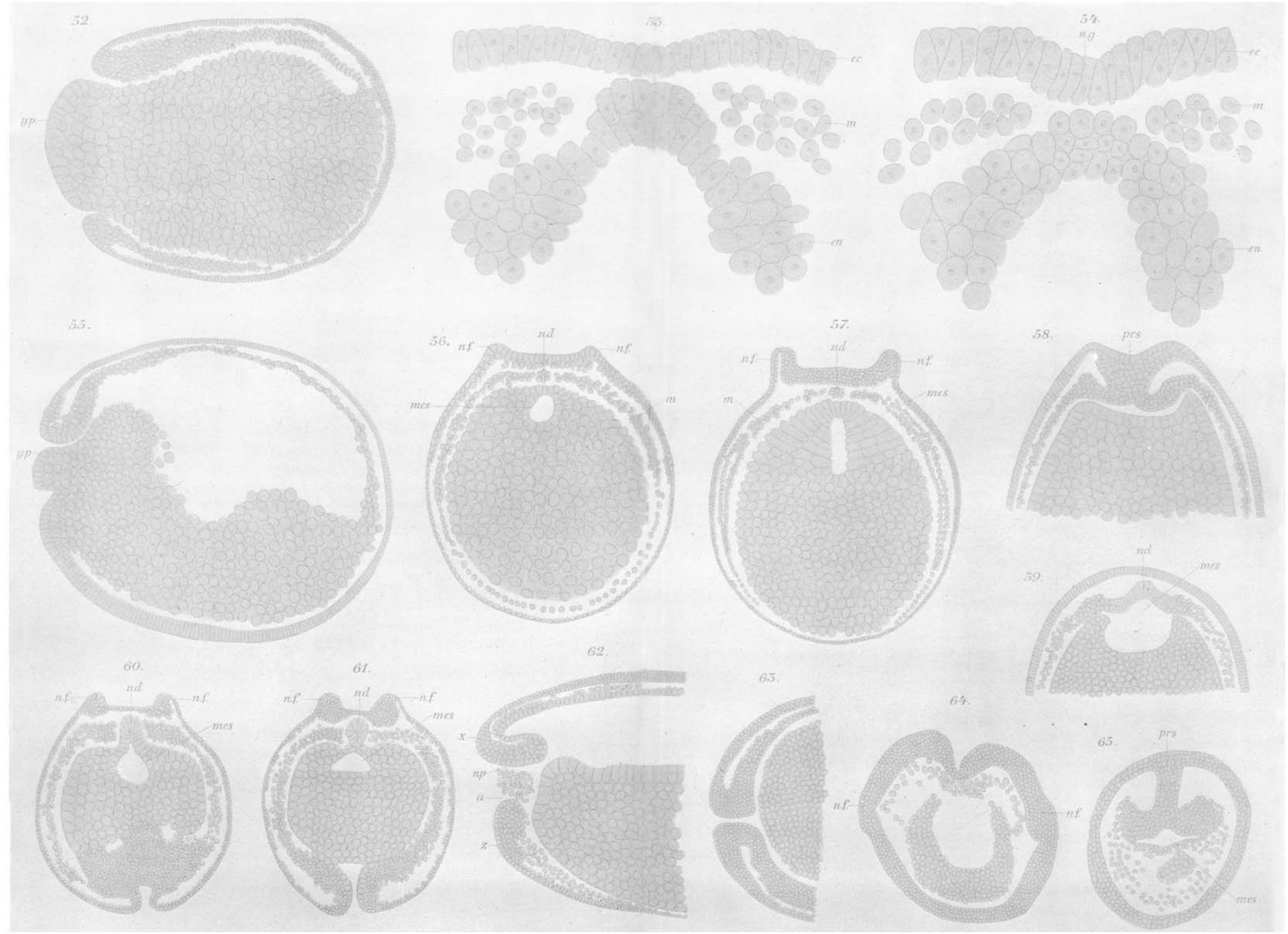

